\title{
Factors found when integrating computer technology in a small rural school district
}

\author{
Edward Dale Jeffreys \\ West Virginia University
}

Follow this and additional works at: https://researchrepository.wvu.edu/etd

\section{Recommended Citation}

Jeffreys, Edward Dale, "Factors found when integrating computer technology in a small rural school district" (2000). Graduate Theses, Dissertations, and Problem Reports. 2381.

https://researchrepository.wvu.edu/etd/2381

This Dissertation is protected by copyright and/or related rights. It has been brought to you by the The Research Repository @ WVU with permission from the rights-holder(s). You are free to use this Dissertation in any way that is permitted by the copyright and related rights legislation that applies to your use. For other uses you must obtain permission from the rights-holder(s) directly, unless additional rights are indicated by a Creative Commons license in the record and/ or on the work itself. This Dissertation has been accepted for inclusion in WVU Graduate Theses, Dissertations, and Problem Reports collection by an authorized administrator of The Research Repository @ WVU.

For more information, please contact researchrepository@mail.wvu.edu. 


\title{
FACTORS FOUND WHEN INTEGRATING COMPUTER TECHNOLOGY IN A SMALL RURAL SCHOOL DISTRICT
}

Edward D. Jeffreys, BS, MS

\author{
DISSERTATION \\ Submitted to the College of \\ Human Resources and Education \\ of \\ West Virginia University \\ In Partial Fulfillment of the Requirements for \\ The Degree of Doctor of Education \\ in \\ Technology Education
}

Morgantown

West Virginia

2000

George R. Maughan, Ed.D., Chair
Don E. McLaughlin
Roy H. Tunick, Ed.D.
Michael T. Yura, Ph.D.
Edward C. Pytlik, Ph.D.

Department of Technology Education

Keywords: Technology Education, Rural School District

Copyright 2000 Edward D. Jeffreys 


\author{
ABSTRACT \\ Factors Found When Integrating Computer Technology \\ In A Small Rural School District \\ Edward D. Jeffreys
}

The purpose of this research study was to provide school board members, school administrators, and teachers with information required in developing a successful plan for the integration of computer technology into the classroom curriculum. The stated problem of this research was to identify and analyze the factors that inhibit and enhance the implementation of computer technology into the classrooms of a small rural school district.

A review of the literature was conducted in the following areas: (a) the use of computer technology in K-12 rural school districts; (b) enhancers to the integration of computer technology into the classroom curriculum in small rural school districts; (c) inhibitors to the integration of computer technology into the classroom curriculum in small rural school districts; (d) research designs in studying technology utilization. The literature review identified three positions as important elements of computer integration: teachers, administrators, and school board members. These three positions participated in the study. The survey return rate for participants was $51 \%$ or 61 participants. The instrument used in this study was designed as a six point Likerttype scale. The data from the two Likert scales were analyzed using a two-way ANOVA. The raw scores were used in the statistical analysis and a significance level of $p \geq .05$ was selected. When required, the post-hoc analysis of significance F-tests was performed using the Fischer's Least Significant Difference Test. The statistical program used in this study was the S-Plus program.

There was a high rate of agreement between the literature review and the positions of teachers, school administrators, and school board members of what enhanced and inhibited integration of computers into the classroom curriculum of a small rural school district. Administrators believe that teachers are one of the most significant reasons that the integration of computers into the classroom has been slow. This research has indicated that the literature review and the results of this research concur; however, the literature review did not give any indication regarding the relationships among the positions and these relationships' impact on the success of computer integration into the classroom curriculum. 


\section{ACKNOWLEDGMENTS}

I am grateful to the following individuals for their assistance, guidance, and general support in the fulfillment of my dissertation. To my dissertation committee: Don McLaughlin, and professors, Dr. Roy Tunick, Dr. Mike Yura, Dr. Ed Pytlik, and Dr.

George Maughan, chairperson. The insight, time, and support that each member of the dissertation committee has given were invaluable. I believe it has been an honor and privilege to study at West Virginia University under the direction of these men.

I would especially like to extend a note of appreciation and thankfulness to Dr. David McCroy, Dr. Faxian Yang, Dr. Bryan Maser, Dr. Cheryl Torsney, Dr. Lynn Dombrowski, Mr. Vincent Neratka, Mrs. Sandy Cale Shoemaker, and Ms. Carol Spiroff.

I would also like to express my deepest appreciation for the support of Mary Jane Cooley Jeffreys. Her constant positive support gave me the courage to continue when things got tough. Thanks, Mom. So many others gave support when I needed it and even though I fail to mention names, you know who you are, and I thank you all so much. Finally, I thank God for the opportunity and privilege to undertake such a monumental task. 


\section{TABLE OF CONTENTS}

TITLE PAGE

ABSTRACT ii

ACKNOWLEDGMENTS iii

TABLE OF CONTENTS iv

LIST OF TABLES $\quad$ ix

LIST OF FIGURES xi

$\begin{array}{ll}\text { CHAPTER } 1 & 1\end{array}$

I. INTRODUCTION TO THE RESEARCH 1

$\begin{array}{lr}\text { Background } & 2\end{array}$

Small Rural School Districts 3

$\begin{array}{ll}\text { Curriculum } & 5\end{array}$

Integration of Computer Technology
into the K-12 Classroom Curriculum

$\begin{array}{ll}\text { Statement of the Problem } & 8\end{array}$

$\begin{array}{ll}\text { Purpose of this Research Study } & 8\end{array}$

$\begin{array}{ll}\text { Significance of the Problem } & 9\end{array}$

$\begin{array}{ll}\text { Research Questions } & 9\end{array}$

$\begin{array}{ll}\text { Assumptions } & 10\end{array}$

$\begin{array}{ll}\text { Limitations } & 10\end{array}$

$\begin{array}{ll}\text { Definitions } & 10\end{array}$ 
$\begin{array}{ll}\text { CHAPTER } 2 & 12\end{array}$

REVIEW OFTHE LITERATURE 12

Introduction 12

$\begin{array}{ll}\text { Part One } & \text { The Use of Computer Technology } \\ \text { in K-12 Small Rural School Districts }\end{array}$

Rural Schools Challenges $\quad 13$

Stephens and Bhaerman Matrix 14

Annenberg Institute for School Reform $\quad 16$

Technology Integration Models 16

McKenze Model 17

$\begin{array}{ll}\text { Picciano Model } & 17\end{array}$

California Model Technology
Schools Projects

Orcutte Union School District $\quad 19$

National Effort $\quad 20$

Chaos Theory and Computer Technology

in Curriculum Integration 24

Summary 26

Part Two Inhibitors to the Integration

of Computer Technology in

K-12 Rural School districts 26

Inhibitors that Act as Barriers to the Successful

Integration of Computers into the Classroom 27

$\begin{array}{ll}\text { Training } & 27\end{array}$

Motivation and Financial Planning 29 
Part Three Enhancers to the integration of Computer technology in K-12 Rural School Districts

Introduction 33

Adoption of an Innovation 33

Enhancers to the Integration Process 35

Exemplary Computer-Using Teachers 37

Difference in Attitude 38

Summary 39

Part Four Review of Research designs in studying

Technology utilization

Research Design Matrix 42

\section{CHAPTER 3}

III METHODS

Description of the Study

Research Design $\quad 45$

Selection of Subjects $\quad 45$

$\begin{array}{ll}\text { Demographics } & 47\end{array}$

$\begin{array}{lr}\text { Instrumentation } & 47\end{array}$

Data Collection Procedures $\quad 48$ 
$\begin{array}{ll}\text { CHAPTER } 4 & 50\end{array}$

$\begin{array}{ll}\text { IV. ANALYSIS OF DATA } & 50\end{array}$

$\begin{array}{ll}\text { Introduction } & 50\end{array}$

Demographics by Position 51

Survey Return Percentage $\quad 52$

Results of Research Questions 52

Survey Results of the Enhancer Items 53

Survey Results of the Inhibitor Items

$\begin{array}{ll}\text { Summary } & 66\end{array}$

\section{CHAPTER 5}

V. FINDINGS, CONCLUSIONS, AND

RECOMMENDATIONS 69

$\begin{array}{ll}\text { Introduction } & 69\end{array}$

$\begin{array}{ll}\text { Summary } & 69\end{array}$

Statement of the Problem $\quad 70$

Findings Regarding Research Question 1 and $2 \quad 71$

$\begin{array}{ll}\text { Findings: Enhancer } & 71\end{array}$

Findings: Inhibitor $\quad 72$

$\begin{array}{ll}\text { Summary } & 74\end{array}$

$\begin{array}{ll}\text { CONCLUSIONS } & 75\end{array}$

$\begin{array}{ll}\text { IMPLICATIONS } & 76\end{array}$ 
RECOMMENDATIONS FOR FURTHER RESEARCH

$\begin{array}{ll}\text { BIBLIOGRAPHY } & 80\end{array}$

$\begin{array}{ll}\text { APPENDICES } & 91\end{array}$

APPENDIX A Integrating Computers into the classroom 92 (Enhancer)

APPENDIX B Integrating Computers into the classroom 95

(Inhibitor)

APPENDIX C Participant letter 98

$\begin{array}{ll}\text { VITAE } & 101\end{array}$ 


\section{LIST OF TABLES}

Table 1. Stephens and Bhaerman Matrix 15

Table 2. Research designs $\quad 41$

$\begin{array}{ll}\text { Table 3. Demographics } & 47\end{array}$

Table 4. Demographic by district by position 51

Table 5. Survey return rate 52

Table 6A ANOVA enhancer item 10

Table 6B Fisher's LSD enhancer item 10

Table 7 ANOVA enhancer item 18

Table 8 Position / District Descriptive Statistics 56 (Enhancer)

Table 9A ANOVA inhibitor item $3 \quad 57$

Table 9B Fisher's LSD inhibitor item 3

Table 10A ANOVA inhibitor item $4 \quad 58$

Table 10B Fisher's LSD inhibitor item $4 \quad 58$

Table 11A ANOVA inhibitor item $6 \quad 59$

Table 11B Fisher's LSD inhibitor Item 6

$\begin{array}{ll}\text { Table 12A ANOVA inhibitor item } 9 & 60\end{array}$

$\begin{array}{ll}\text { Table 12B Fisher's LSD inhibitor item } 9 & 60\end{array}$

Table 13A ANOVA inhibitor item 11

Table 13B Fisher's LSD inhibitor item 11

$\begin{array}{ll}\text { Table 14A ANOVA inhibitor item } 12 & 61\end{array}$

Table 14B Fisher's LSD inhibitor item 12 
Table 15A ANOVA inhibitor item $13 \quad 62$

Table 15B Fisher's LSD inhibitor item 13

Table 16A ANOVA inhibitor item 18

Table 16B Fisher's LSD inhibitor item 18

Table 17A ANOVA inhibitor item $20 \quad 64$

Table 17B Fisher's LSD inhibitor item 20

Table 18A ANOVA inhibitor item $19 \quad 65$

Table 18B Fisher's LSD inhibitor item $19 \quad 66$

Table 19 Position / District Descriptive Statistics 67 (Inhibitor) 


\section{LIST OF FIGURES}

Figure 1. Enhancer item E18 


\section{CHAPTER I}

Introduction

Computer technology has been used in both education and training for over thirty years (Seidel \& Perez, 1994; Hunter \& Richards, 1996). Its use in today's classroom is neither an end in itself nor an addition, but rather a tool for improving and ultimately transforming teaching and learning. Technologies, like computers and the use of the internet, tend to remove barriers such as age and regional idiosyncrasies from educational settings (American School Board Journal, 1997). In the broadest sense, technical communication technologies extend our abilities to change the world (American Association for the Advancement of Science, 1989; U.S. DOE. 1996).

One of the most revolutionary technological developments of the past four decades has been the advent of the use of computer technology (Means, 1993; Global School Net Foundation, 1996). Today, as we use the computer at the home or office, we can be assured that computer technology will never be far from our fingertips. Nua Internet Surveys (1998) indicated that in 1998 there were 62 million adults age 16 and over using computers to access the internet in the United States. Additionally, their surveys reported that over half of the Americans with personal computers were online and on the internet. Seven million more intended to be online within six months, suggesting that the population using computers to access the internet would reach 70 million by the end of 1998 (Nua, 1998). When assessing the use of computers, it can be seen that the internet can also be a tool for possible use in the classroom. The internet is a worldwide network of computer networks designed to foster high-speed communication and information exchange. 
It uses a common communication protocol, which permits file transfer, electronic mail, and remote login from one computer to another (Yocam, 1996). As Yocam noted, the internet is a global infrastructure for education, research, government, business, organizations, and facilitates their ability to access, share, and distribute information. Yocam cautioned that there is much to be learned in order to benefit from and make full use of the internet's use in the classroom. Yocam (1996), and Means (1993) pointed out that computer technology use in schools has been less than adequate. They noted that computer technology in the classroom was typically being used for word-processing device rather than as an extension of the subject content.

The use of computers with access to the Internet is only a part of the overall use of technology in schools. Molseed (1997) suggested that rural school district leaders should develop a school reform plan or model for the implementation of computer technology. This should be a process that would assist in achieving the overall outcomes of each school district's educational reform plan. Molseed (1997) also believed that computer integration and school reform were not synonymous. Computer integration was only one variable in the overall plan. School reform involves many more variables such as teacher training, community involvement, and class size.

\section{Background}

For more than 250 years, America's rural schools were the nucleus of American education (Stern, 1994; Gulliford, 1996). Rural America and rural schools have attempted to change to meet the needs of its population. The 1998 economic 
shift of putting increased educational funding in line with Goals 2000 has helped to create obstacle after obstacle for rural American schools. The most recent call for school reform has prompted administrators of rural school districts to explore avenues that would assist them in the challenge of preparing their students to compete in the labor market of the twenty-first century.

Many resources of interest to schools, academic institutions, educational agencies, and libraries were available through the use of computers with access to the internet. Some examples of these resources included electronic journals, books, online public access catalogues, databases, and bibliographies. Brody (1995) noted that many schools were able to access information in subject areas, such as the study of global disarmament, employment, literacy training, as well as computer technology for the handicapped. These are examples of the effective use of computer technology. Even though the use of computers with access to the internet had been available for over twenty years, it became an accessible tool for the educational community only at the close of the $20^{\text {th }}$ century. As teachers, librarians, administrators, and higher education staff began using computers, they discovered a world of information and global connectivity opportunities.

\section{Small Rural School Districts}

The lack of a clear, widely accepted definition of "rural" has impeded research in the area of rural school districts and education. It was necessary to define what areas were rural in order to determine the number of students residing in rural areas and to describe the characteristics of educational programs and curriculum needed for these students. To classify the rural/non-rural status of 
school districts more precisely, (Perelman, 1992; Cradler, 1995,) created a districtlevel file that used local codes from the Common Core of Data (CCD) Public School Universe file. The 1990 data suggested that, based on the types of school districts students attended, $43 \%$ of school districts were rural. In 1993-94, about 1,100,000 of the nation's $43,200,000$ public school students were enrolled in a small rural school district (Nua, 1998). The average student enrollment of a rural school ranges from 200 to nearly 1100 students. Perelman, 1992; Cradler, 1995, suggested that the appropriate definition of a rural school district was a rural community with a population ranging from 1500 to 2000 community members and a student population of 200 to 1200 . Small rural districts were reported to have slightly more students (10\%) requiring Individualized Education Programs (IEPs) than city and urban schools. During the latter part of the period from 1986-94, overall, the US school enrollment increased while small rural districts enrollment remained virtually constant, at about 12\%. From 1987-88 to 1993-94, there was a gradual increase in the proportion of students with IEPs in small rural districts.

Often the implementation of an appropriate IEP required additional funding above that of a non-IEP student. As Willis (1994) has suggested, when the district attempted to supply a curriculum that meets the student's IEP requirements, this in turn created additional financial burdens on the small rural school district. The public had a general attitude that small rural school districts were unable to provide a full curriculum for each student. The idea that the public has the general attitude that small rural school districts are unable to provide a full curriculum would support Brody (1995) stated that small rural school districts were not preparing their students 
for the twenty-first century workplace. However, Howley (1994) stated that schools characterized by aspects such as students with a more positive attitude about school were more likely rural than urban.

The United States public school system included a total of 16,000 school districts with a student enrollment of 40 million students and three million teachers (Picciano, 1994). In the nation as a whole, there were no substantial discrepancies in per-pupil revenues and expenditures between small rural districts and larger school districts (Nua, 1998). In 1992-93, revenue per pupil in small rural districts was about $\$ 6,200$, and expenditures per pupil were about $\$ 6,000$. This was about $\$ 200$ to $\$ 400$ more than in large non-rural districts. The per-pupil revenue and expenditures were only about $\$ 5,200$ in large districts. Per-pupil spending varied substantially between regions. Most notably, small rural districts in western regions spent nearly $\$ 2,000$ more per pupil than in other larger districts.

Nearly half the revenue in small rural districts came from local and state sources, with about $7 \%$ from the federal government (Nua, 1998). About two-thirds of the current expenditures in small rural districts were for core instruction, slightly less than the large school districts. After adjusting for inflation, finance trends for rural school districts between 1989-90 and 1992-93 remained unchanged.

$\underline{\text { Curriculum }}$

Perhaps the most dramatic proof that supported the theme of the poor general quality of our education curriculum was that industry reported that the lack of quality employee education in the basics such as math and English was at an alltime high (Picciano, 1994). But times were changing in our public schools. School 
districts had new challenges, and the school systems were changing to adapt to these new challenges (Sheingold, 1991; Chickering \& Ehrmann, 1997). Computer technology played a major role in meeting these challenges. Computer integration permitted school districts the opportunity to add a variety of courses that previously, due to cost, school districts were unable to offer. The integration of computer technology into schools could be a positive experience, provided a plan or model was developed (Sheingold, 1991; Chickering \& Ehrmann, 1997). .

The focus of this research was to identify and investigate the factors that acted as inhibitors or enhancers to integrating computer technology into the classroom curriculum within a rural school district. Three school districts meeting this criterion were Turkeyfoot Valley Area School District, Myersdale School District, and Rockwood Area School District. These school districts had much in common and were located in Somerset County, in south-western Pennsylvania, 76 miles south-east of Pittsburgh and 30 miles north-east of Garrett County, Maryland. The largest employers within these communities were retail sales, construction, manufacturing, health services, and personal services. With unemployment averaging between thirteen and twenty percent, and a low tax base, these rural school districts were committed to integrating computers into their classroom curriculum. 
Integration of Computer Technology into the K-12 Classroom Curriculum

Rural school districts have always been at a disadvantage in trying to keep up with some urban schools because the latter possess that fortunate balance of educated populace and money (Means, 1994; NCES, 1998). Considering this lack of balance of educated populace and money, it was understandable that small rural school districts had a major economic challenge at hand when they decide to integrate computer technology into the classroom curriculum. The integration of computer technology into K-12 education and the Education Reform movement were two of the most significant trends in education today (Means, 1994; NCES, 1998). Perhaps never before had any innovation had the potential to assist in education reform, as had the integration of computer technology in the classroom. Perlman (1992) suggested that computer technology would forever alter the tasks of the classroom teacher, and that the teacher would no longer be the main character in American education. Knapp \& Glenn (1995) suggested that successful computer integration in schools must include curriculum planning and a model that was supported by those involved with the plan of computer integration. Selecting the appropriate integration model was a difficult task for most school districts because of the many different variables each district may have. McKenze (1993) and Picciano (1994) developed computer integration models for integrating computer technology into the classroom. When reviewing these models, four components became evident in each model and they were:

1) A strong, well thought-out overall plan.

2) A curriculum development plan. 
3) A plan for community support.

4) Training for staff.

All of the successful computer technology integration models included the four components mentioned above. (Picciano, 1994). However, computer technology integration models also needed to include other components to complete their particular goal or objective. The primary purpose of integrating computer technology into education was to improve the quality of students' education (Hertzke \& Olson, 1994; Knapp \& Glenn, 1996). The questions proposed were "How do we accomplish this task? and "Where do we begin?" It was important to clarify the use of technology and computer technology integration as discussed in this research. The term "technology" and "computer" were often assumed to be synonyms. Computer technology is but a small part of our technological world. This research identified the inhibitors and enhancers to the implementation of the computer technology into the classroom curriculum of a small rural school.

\section{Statement of the Problem}

The problem of this research was to identify and analyze the factors that act as inhibitors and enhancers to implementing computer technology into the classroom curriculum of a small rural school district.

\section{Purpose of this Research}

The purpose of this research was to provide school board members, school administrators, and teachers with information required when developing a successful plan for integrating computer technology into the classroom curriculum. 


\section{Significance of the Problem}

One of the primary objectives of school districts was to prepare students for the work place of the twenty-first century (Sheingold, 1991; DeYoung, 1995;). However, little had changed since (Sheingold, 1991; DeYoung, 1995;) reported that the real challenge of integrating computer technology into a school's curriculum was much more human than technological. He believed that the real challenge was in changing the attitude of teachers about computer technology. The school reform movement was more than ten years old, and computer technology had become one of the primary driving forces in this process of education reform, yet there had been little success when integrating computer technology into the classroom curriculum (Rogan, 1997). As more information and computer applications became available, the importance of computer technology integration and teacher computer literacy became even more evident.

\section{$\underline{\text { Research Questions }}$}

This research investigated the following questions:

1. Were there differences among the positions of teachers, school administrators, and school board members regarding enhancers and inhibitors to the process of integrating computers into the classroom curriculum?

2. Were there differences between school districts regarding their opinion of enhancers and inhibitors to the process of integrating computers into the classroom curriculum? 


\section{Assumptions}

For this research, it was assumed that:

1. Data collected was accurate and true;

2. Group size did not affect the outcome of this study.

3. Variables were of normal distribution.

\section{Limitation}

This research study had the following limitation:

1. This research was limited to the three groups from three rural school districts:

7-12 teachers, administrators, and school board members.

\section{Definitions}

The following definitions apply to this research:

Administrative Support: Financial and moral support supplied by school administrators.

Electronic Mail (E-mail): The processing and delivery of messages via electronic means. Users of electronic mail interact with each other through computer terminals or microcomputers connected to a shared communications network (Edumunds, 1985).

The internet: A network of computer networks used by millions of people all over the world (LaQuey, 1994).

Professional Development: The process of increasing subject matter knowledge, teaching skill and efficiency, and creating insight into educational problems, with a desire to achieve success as a teacher. 
Individual Educational Plan: A specifically developed curriculum of study designed for a specific individual, usually a student who has academic, physical, or social challenges in the classroom. This would also include the student identified as being gifted.

Hardware: Physical devices or computers.

Software: Programs or written instructions for a computer.

Rural School District: $\quad$ A rural area is comprised of places or communities with fewer than 2500 residents. A rural school district will typically exist within the boundaries of the rural community with a student population of 200 to 1200 (U.S. Department of Agriculture, 1999). 


\section{CHAPTER II}

Review of the Literature

\section{$\underline{\text { Introduction }}$}

The purpose of this section of the research, the literature review, was to present the framework from which the researcher based this study. This literature review investigated the following areas: small rural school districts, curriculum reform, and inhibitors/enhancers to integrating computer technology into the K-12 classroom curriculum. The focus of this review was divided into four areas of inquiry: 1) the use of computer technology in K-12 rural school districts; 2) the definition of the inhibitors to integrating computer technology in K-12 rural school districts; 3 ) the definition of the enhancers to integrating computer technology in K-12 rural school districts; 4) the review of research designs in technology utilization.

\section{Part 1:The Use of Computer Technology in K-12 Small Rural School Districts}

Historically education in America began as a nation of rural schools (Barker \& Hall, 1998). The US Census Bureau defined a rural area as one that was not urban and had a population of less than 2,400. The US Census Bureau also reported that an estimated $27 \%$ of all public schools were located in rural areas. Barker \& Hall, (1998) stated that the origin of formal education was initially left to the family. Barker \& Hall (1998) also suggested that rural schools outnumbered urban schools. Rural schools continued to follow the educational models used in urban school districts with a different population, thus creating additional problems for the administrators of small rural school districts. 
However, some researchers (Howley, 1994; Davenport, 1995) reported that small rural schools shared a number of more positive elements. Howley (1994) considered community attitude to be important, and rural communities tended to support their schools; thus, parental satisfaction as well as student participation was higher at rural schools than at urban schools. Howley (1994) also reported that, in general, student drop-out rates were lower at rural schools than at urban schools, and in many cases a superior achievement rate existed among lower socioeconomic status homes located in a rural area than in similar homes in urban school districts. This was due in part to the fact that schools had in many ways replaced the family. Schools provided breakfast and lunch, and in some districts dinner.

Howley (1994) suggested there was evidence that rural schools facilitated a more effective classroom delivery system due to their small size. This supported Howley's (1994) position that rural schools provided a more nurturing and satisfying program for preadolescents. (Barker \& Hall, 1998; Elder, 1991) reported that in 198990 , almost half or $47 \%$ of the nation's rural school districts had enrollments of fewer than 200 students, permitting small class size in most cases.

\section{$\underline{\text { Rural School Challenges }}$}

One of the serious challenges to the small rural school was the inability to retain or recruit faculty and staff. Many believed that these small rural school districts offered many advantages over the larger city or urban school districts as indicated earlier; however, having a small student enrollment also brought with it a wide variety of challenges. Kimpton \& Sharp (1997) reviewed "America 2000: The Rural Disadvantage" and suggested that small school districts experienced great difficulties when attempting to enrich their curricular offerings due to small enrollment and staffing limitations. The authors further stated that rural schools' ability to recruit and retain staff with training in advanced math and sciences is far below that of the suburban school districts. Kimpton \& Sharp (1997) stated that rural school districts could look forward to 
the difficulty in achieving a graduation rate of 90\%; however, Howley (1994) disagreed. He stated that standards would shift to accommodate the need for districts to show a high graduation rate. Kimpton \& Sharp (1997) further suggested that rural school districts would have little difficulty in implementing school-based decision-making, and this would be a very positive position. Stephens and Bhaerman (1992), in their review of literature about rural school districts, maintained that the solution for the challenges of small rural school districts was to focus on the strengths.

\section{Stephens and Bhaerman Matrix}

The matrix which Stephens and Bhaerman (1992) developed shows commonly acknowledged strengths and challenges that is unique to small rural school districts. Stephens and Bhaerman (1992) also suggested that small rural school districts had unique challenges as well as unique strengths such as those listed above (see Table 1). However, the greater challenge was what standards or models should be used to assess the strengths and challenges of the small rural school district. What was the ideal model that would accept the strengths and resolve the challenges? Baugh (1994) found that the Concerns-Based Adoption Model from the Research and Development Center for Teacher Education at the University of Texas at Austin assisted her in her research on the infusion of the internet into the classroom of a small rural school district in West Virginia. 
Table 1

Stephens and Bhaerman Matrix

\begin{tabular}{|c|c|c|}
\hline Indicators & Common Issues & Common Strengths \\
\hline $\begin{array}{l}\text { School-community } \\
\text { Identification of the } \\
\text { Characteristics }\end{array}$ & $\begin{array}{l}\text { declining population; local fiscal } \\
\text { stress; } \\
\text { higher than national average } \\
\text { unemployment and poverty; } \\
\text { Lower personal income; poor } \\
\text { Infrastructure }\end{array}$ & $\begin{array}{l}\text { generally strong } \\
\text { community with } \\
\text { the school }\end{array}$ \\
\hline $\begin{array}{l}\text { School system } \\
\text { Characteristic }\end{array}$ & $\begin{array}{l}\text { smaller enrollment size drives up } \\
\text { per-pupil cost } \\
\text { generally less local decision making }\end{array}$ & \\
\hline Fiscal characteristics & revenues; generally higher local effort & \\
\hline Staff characteristic & inability to recruit and retain staff & $\begin{array}{l}\text { generally strong } \\
\text { identification with } \\
\text { community. }\end{array}$ \\
\hline Student characteristics & & $\begin{array}{l}\text { generally many } \\
\text { opportunities } \\
\text { for developing } \\
\text { leadership skills }\end{array}$ \\
\hline Parent involvement & & $\begin{array}{l}\text { generally strong, } \\
\text { continuous } \\
\text { parental } \\
\text { involvement }\end{array}$ \\
\hline Facilities characteristics & $\begin{array}{l}\text { generally less comprehensive } \\
\text { specialized space }\end{array}$ & \\
\hline Program characteristic & $\begin{array}{l}\text { lack of breadth and depth } \\
\text { especially in science and math, } \\
\text { languages, and } \\
\text { vocational/technical education }\end{array}$ & \\
\hline $\begin{array}{l}\text { Secondary teaching } \\
\text { instructional characteristics }\end{array}$ & & $\begin{array}{l}\text { generally smaller and } \\
\text { classes sizes, greater } \\
\text { individual attention }\end{array}$ \\
\hline $\begin{array}{l}\text { Organizational } \\
\text { Characteristics }\end{array}$ & & $\begin{array}{l}\text { generally a safe } \\
\text { environment }\end{array}$ \\
\hline
\end{tabular}


Baugh's (1994) findings indicated, in part, that training was a critical factor in the possibility of a successful integration plan. Also identified, as a critical factor, was a support system for the teachers after the technology plan was instituted.

\section{Annenberg Institute for School Reform}

In 1996 the Annenberg Institute for School Reform undertook a study of the methods used by parents, students, and the public to organize their efforts to revitalize public education across the country. "Reasons for Hope, Voices for Change," a report developed from this study, summarized what the group learned. Kimpton and Sharp (1997) contributed to the Report. They believed that public schools were crucial to the sustained vitality of American democracy. This belief supported the point that the selection of a specific computer technology model for education reform must include extensive community involvement. The following are examples of integration models used by other school districts.

\section{Technology Integration Models}

The primary purpose of the integration of computer technology into education was to improve the quality of education that students receive. The questions proposed were: 1) How do we accomplish this task? 2) Where do we begin? The major variables included curriculum development, grade level, teacher skills, administrator skills, access, technical infrastructure, technical support, scheduling, budgets, student needs, community involvement, and the overall school district plan of computer technology integration. It was important to clarify the use of computer technology and technology integration. 


\section{McKenze Model}

McKenze (1993) developed a model for integrating computer technology into a school district. He termed it a comprehensive approach, which identified the importance of the following elements:

1) Anticipating the future.

2) Creating planning committees for the stakeholders.

3) Providing staff development.

4) Winning community support.

5) Identifying and obtaining new sources of funding.

The McKenze (1993) model addressed most of the primary elements needed in a model; however, he did not include the elements of technical infrastructure, technical support, student needs, and curriculum development.

\section{Picciano Model}

Picciano (1994) developed a model based on the social process model. In this model he included environment, culture, values, goals, school district, evaluation, infrastructure, applications, staff, hardware, software, facilities, finances, and on-going feedback. The Picciano (1994) model was more comprehensive than McKenze's (1993) model because Picciano had taken a holistic approach to developing the model. He suggested that external environmental scanning was an important element of his model.

Picciano explained his holistic model as the process of engaging in activities to provide information on the community, state, and society for planning purposes. He included in the holistic model the basic assumption that an administrator would provide the needed leadership to convert environmental values and conditions into the goals and objectives of the school districts. The Picciano model also showed what he believed was a holistic approach to the integration of computer technology. It was in 
many ways, similar to the Riedl (1995) model, but the Riedl model placed significant importance on teacher in-service training as a primary catalyst for success.

\section{California Model Technology Schools Projects}

John Cradler (1994) researched the California Model Technology Schools

Project and offered it as a complete model. Cradler's research yielded findings that identified critical components necessary for technology integration in the schools. He described the California Model as an eleven-step model for the successful integration of technology into the classroom. Cradler's first step was to establish a stakeholder planning committee, to focus on a comprehensive plan that involves all of the stakeholders. These stakeholders included school administrators, community, community leaders, students, faculty, vendors, and support staff. Additional critical factors included establishing a vision for the plan, which included using existing and emerging resources, and basing computer technology decisions on curriculum and instructional needs. Also proven to be important was the focus on students, providing for local staff development, and follow-up assistance.

Cradler (1992) emphasized that school and district plans could only be implemented if teachers were developing and implementing classroom plans or projects that directly support the objectives of the school district integration model. His statement was that it was easy to get excited about how technology would transform schools, but technology alone was but a tool and would only people more schools to prepare students for the twenty-first century workplace. Technology would not take the place of sound decision-making by the stakeholders involved in the technology integration process. Integrating computer technology into K-12 education required a number of discrete changes in the ways classrooms were structured. This process also required a new look at the involvement of the community and all that it could offer. In this newly created environment, student diversity had to be respected and rewarded. 
The Orcutte Union School District was an example of this approach of community involvement.

\section{Orcutte Union School District}

The superintendent of the Orcutte Union School District suggested that the success of his district integration model was based around the same five elements as Brody (1995). The superintendent believed, as did Brody, that technology planning and implementation was a joint effort, and the more support from school, students, faculty, parents, and the community, the greater the chance of success.

Brody (1995) suggested that the successful integration of computer technology in the schools must include curriculum planning. Brody believed that the Factory model has proven to be successful in the past and will continue to be successful in the future. The Factory model for integrating technology into the classroom has as its anchor a strong belief that accountability was necessary. In this model, accountability was used as the driving force to success.

Most of the models reviewed for the integration of computer technology into the schools had these same four components:

1) A strong well thought out plan.

2) Curriculum development.

3) Community support.

4) Training for all staff and faculty.

(Hertzke and Olson, 1994; Knapp and Glenn, 1996). However, all computer technology integration models also included various other components that would complete the plan of each individual school district. One model reviewed that had what appeared to be the most comprehensive plan to date was the California model, discussed earlier. 


\section{National Effort}

According to the Annenberg Report "Reasons for Hope, Voices for Change" the models discussed earlier would have had a greater success if they had included public engagement. Kimpton and Sharp (1997) chronicled how people, schools, and communities were providing proof that a more diverse constituency had the ability to empower and lend long-term support to education reform. The report followed an 18month study into the methods of how schools, parents, and the community became catalysts for the public education reform movement. The theme of public engagement $(P E)$, while not new, had taken on new life. PE is based on the premise that empowerment came when vital interaction occurred between people and institutions.

The PE effort had three basic characteristics: inclusiveness, focus on change, and consensus. Inclusiveness was considered to be the involvement of citizens from all segments of the community. Focus on change was defined as an effort to change and improve the life of the local community. Consensus meant that an effort was directed to build, inform, and deepen the local conversation around issues of importance to the community for the purpose of developing broad support for action. Kimpton and Sharp (1997) believed that by targeting these three characteristics, communities would develop the ability to tackle difficult issues and make tough choices. The report also suggested that PE had the potential to assist school districts in making the choices that lead to a successful educational reform that included the integration of computer technology into the classroom curriculum. 
Kimpton and Sharp (1997) suggested that the public was disappointed with the lack of results in public education reform in America. Parents and community members were asking for change that would result in increased student achievement. In answering the question of whether or not our public school standards were too low, a resounding $60 \%$ of those responding answered yes. Kimpton and Sharp (1997) "Annenberg Report" indicated that parents, (80\%) believe teachers to be the most committed to public school reform. Parents rated schools at $73 \%$, and superintendents at $70 \%$ committed. According to the Annenberg Report these percentages indicated a lack of information sharing on the part of those involved with this change and the inability to communicate that information and show that school reform was a team effort.

In the report "Reasons for Hope, Voices of Change" the Plainfield Public Schools, Plainfield, NJ, offered as an example of what Public Engagement can produce. A new superintendent faced a community with a population of 46,000 and a diverse range of income levels. Dissatisfaction with the school district and the administration was at an all-time high, and parents were removing children from Plainfield Public Schools and moving them to private ones. The superintendent began his Public Engagement effort by publishing information about student standardized test scores, district finances, and the poor condition of the physical structure of the district buildings. This was the first time the community had received this type of information. His next effort was to appoint a seventeen-member community task force. The task force included business members, community members, educational professionals, and political leaders, either appointed or elected. This task force grew to 225 members, and 
within the next few months the task force had developed a blueprint for the school district's future.

Not long after the blueprint was presented to the community, the teachers' contract was due for ratification. The contract was ratified quickly, due in part to the superintendent's earlier innovation of inviting a conflict resolution expert into the district to present a program on conflict resolution to the task force. According to the report "Reasons for Hope, Voices of Change" the Planifield Public schools the teachers gave back $0.5 \%$ of the salary increase they had received just months before. Within the first two and a half years, the district taxpayers issued a vote of confidence for the school district in the form of a $\$ 33.9$ million bond issue. An interesting footnote was that while the district did move on and develop a future plan, standardized student test scores did not improve. Leverett offered no reason for the lack of change in the test scores.

The emphasis on integrating computer technology into the classroom curriculum has been blamed for the rise in anxiety and fear in teachers, administrators, and students. Piotrowski (1992) suggested that teachers and administrators often felt that computers were not that important, and believed that since technology changed so rapidly, it would be unwise to waste the taxpayers' money to purchase something that would soon be obsolete. This rationale was often followed by the statement that training teachers today was wasting money since technology would change constantly. Wesley and Franks (1994) reported that teachers had a positive outlook and would adopt computer technology only after they understood and accepted its uses and benefits. 
Many studies investigated how teachers, administrators, and students feel about the use of computers and the adoption of computer technology into the classroom curriculum (Barker \& Hall, 1998; Caffolla and Knee, 1998; Becker, 1994). One such study was conducted at the Highland Park Elementary School in Austin, Texas. The purpose of the study was to determine how teachers' attitudes towards computers affected computer integration into the classroom curriculum. The study was also used to measure attitude change after the process of training was implemented. The results showed that within the first twelve months teachers' attitudes changed in several ways. Before training, teachers were divided $50 / 50$ in favor of integrating computers into the classroom. However, after the training, $85 \%$ of the teacher's valued teaching with computers, while $97 \%$ agreed or strongly agreed that using technology would enhance their teaching and ultimately improve student performance. The study also reported that during the 12 months of follow-up, teachers increased the use of computer technology in the classroom curriculum. This high rate of success was directly related to the amount of training the teachers received.

Poindexter (1997) developed what she termed the "Rural School Consortium" solution. She described the challenge of four small rural school districts in Indiana that were experiencing major challenges implementing a school reform plan that included technology integration. Recognizing the power of unity, these four small rural school districts pooled their resources and developed a consortium to coordinate the resources of the four small rural school districts. The consortium chose staff development as their first step of school reform. Success was achieved in the first of many steps in their plan of school reform. This consortium effort appeared to have many of the elements that 
Kimpton and Sharp (1997) presented in the report "Reasons of Hope, Voices of Change."

Chaos Theory and Computer Technology in Curriculum Integration

When most people think of chaos theory, they believe that the term relates only to mathematics and science (Stickel, 1992). Stickel and others defined chaos theory as a process dealing with diversity, change, synthesis, and turbulence Stickel (1992). The authors further suggested that many of the chaos theory constructs might be useful in the use of computers in schools. They further suggested when using chaos theory constructs in developing a plan for computer use in schools, the focus should not be on confusion and lack of order, but instead on the complexity of the task of computer technology integration. Stickel (1992) proposed that the use of five constructs of chaos theory would be appropriate for this task. The chaos theory constructs that could be used in developing student use of computers in the classroom were identified as sensitive dependence, phase space, iteration, turbulence, and fractals.

Sensitive dependence is the construct that describes when a small variance occurs, such as when a student attempts to add a new program to the hard drive and memory space is not available. Usually the system will lock up or freeze. The events that follow, such as student attempts to solve the challenge by various entries, will lead to a less logical or series of random entries to clear or solve the challenge at hand. This construct shows that a small event will lead to a much larger undesirable consequence (Stickel, 1992). Conversely, this construct could aid teachers in helping students understand that even small changes over time will grow in size and effect. 
The phase space construct when applied to computer integration is thought of as having all the knowledge to know about the relationship between the computer and the student user. This construct could help the teachers explain to students that learning how to use computer entails many more variables than simply hitting a key. Students must first understand the task at hand and the power of the computer.

Construct iteration is simply how a student understands the feedback and feedback loops that are developed when he or she continues to use the system. Basically, the system then builds on itself through their understanding of the constructs. Teachers could use this construct to help the student understand that the relationship between the computer and the user constantly changes. The more the user interacts, the more feedback he or she receives.

The construct of turbulence was described as the presence of energy that creates disorder (Stickel, 1992). The use of this construct could allow teachers to recognize excessive student enthusiasm toward a certain computer activity and to redirect student users to a new computer activity. The fifth construct that Stickel (1992) offered was fractals. Stickel suggested that fractals employ irregular geometry rather than Euclidean geometry to display certain shapes. Teachers could aid students in the use of fractals on the computer in the introduction of mathematics and geometric concepts as well as algebra, technology, and pattern recognition. The five chaos theory constructs presented by Stickel (1992) could be relevant for use in education and support computer integration into the classroom. 


\section{Summary}

Galbraith (1992) reported that the future of rural school districts could be a story of struggle and survival, and if action was taken in time, the story could very well be one of success and achievement for the students and the community. Thus a plan or model that met the precise needs of each school district was critically important. Various technology integration models were presented that have been successful for small and large school districts. However, no models had all the elements to respond to a small rural school district's needs. Reviewing the use of computer technology in K-12 small rural school districts raised as many questions as it offered solutions. One serious question raised was the cost of implementing a computer integration plan or model. If it was assumed that the use of computer technology in the classroom would assist small rural school districts in their efforts of education reform, then the plan or model must be designed for that specific school district. Stephens and Bhaerman (1992) suggested that small rural school districts have unique challenges as well as unique strengths; however, the challenge was in deciding what standard or models should be used as the strengths and challenges of the small rural school district were assessed. Each school district, large or small, will have different needs. All elements must be taken into consideration and a plan developed that would focus on the positive characteristics of a small rural school district. In order to analyze the data reviewed, it must be assumed that the first priority of a small rural school district was to develop an all-inclusive plan or

model that would meet the specific needs of the district students, staff, and community.

\section{Part Two: Inhibitors to the Integration of Computer}

\section{Technology in K-12 Rural School Districts}

It has been stated by Galbraith (1992) that rural America is currently in a social, educational, political and economic crisis. He also suggested that at the heart of the solution of this crisis was the process of lifelong education and learning. Galbraith 
believed that technology has provided opportunities for lifelong learners to engage in learning by providing alternative forms of instruction. Education reform could aid in the further development of a educational base desired by most school districts involved in education reform. Many small rural school districts have attempted to conduct school reform without experiencing success at any significant level. Many authors proposed that the use of technology is at the center of education reform for schools (Rapp,1997). Marcinkiewicz's (1993) research indicated that teachers who had access to computers were underutilizing them in the classroom. Rapp (1997) stated that for full integration of computers in the classroom, the administration must fully understand the concerns of the teachers. As with education reform, technology integration has fallen short of the desired results (Brickner, 1995). Brickner suggested that rural schools have certain built-in challenges that inhibit the integration of computer technology. The following review of literature identified a variety of inhibitors to the success of computer integration into the classroom.

\section{Inhibitors Acting as Barriers to the Successful}

\section{Integration of Computers into the Classroom.}

\section{Training}

One of the most serious problems that faced school districts, at the end of the $20^{\text {th }}$ century, and specifically small rural school districts, was the maintenance of a highquality educational program that would prepare students for the twenty-first century workplace. Through the use of computer technology, small rural school districts had the opportunity to achieve the desired high-quality education programs (Sasala, 1994). However, before this success could be achieved, the inhibitors to the integration process had to be identified and corrective action taken (Bolton, 1994). Bolton found five inhibitors to the integration process and suggested that if these inhibitors were not eliminated, failure was imminent. The inhibitors Bolton identified were: 
1) Leadership or the lack of strong leadership.

2) The lack of appropriate training for teachers, administrators, and students.

3) Inadequate financial planning.

4) Availability of computers.

5) Teacher attitude.

Owens (1995) suggested that other inhibitors included:

1) Lack of school-day time for learning and using technology.

2) Lack of teachers' ability to design meaningful educational activities.

3) Inadequate computer skills.

4) Lack of skill on how to incorporate technology into the classroom curriculum. Shoemaker (1997) suggested in her research findings that the major inhibitors included the following:

1) Funding.

2) Lack of training.

3) Lack of time.

4) Lack of resources.

5) Failure to develop a long-term plan.

Rapp (1997) stated that the overall access to computer hardware and software in individual schools must be adequate if computer technology was to become part of the student learning environment. He also believed that the lack of training in computer technology for teachers in the areas of lesson planning, delivery, research, and ways to promote hands-on student learning were major inhibitors. Brichner (1995) completed a study that showed major inhibitors to be the lack of access to computers for students and teachers, lack of support and long-term commitment from administration and a lack of an instructional model for teachers when they use computers in the classroom. Brickner (1995), Kearsley and Lynch (1992), and Willis (1994) suggested that the following must be considered major inhibitors: 
1) Inadequate training of administrators, teachers, and students.

2) Lack of a long-term plan that would also include funding strategy.

3) Selection of appropriate hardware and software.

4) Lack of considering human resistance to change.

Inadequate training of administrators, teachers, and students was not a new inhibitor to the integration of computers into the classroom. Davenport's (1995) research indicated that administration must have a plan for on-going training and support for teachers and students. Kearsley and Lynch (1992) reported that effective available training for administrators, teachers, and students has long been a major inhibitor to the use of computer technology. The training needed today is different than training in the past. Instead of training in areas such as formatting a disc, focus should be on the motivational level for the teacher in the areas of lesson planning, instructional delivery, research, and how to promote hands-on student learning (Willis, 1994). Willis also suggested that without follow-up assistance after the training, along with peer coaching and departmental planning, the possibility of success was slim. Motivation and Financial Planning

Harvey (1990) also believed that a lack of teacher training would result in teachers feeling incompetent in using computers and integrating technology into the classroom curriculum. Scheidler (1994) believed that successful change most often fails because teachers were not properly trained. Also cited as a major inhibitor to the computer integration process was the lack of teacher motivation (Scheidler, 1994). Lack of financial planning continued to be a main focus as a major inhibitor to computer integration. Kearsley \& Lynch (1992) believed that financial planning was a weak link in most school districts' plans. Bushwellers' (1996) research "Educational Vital Signs" reported that the dollar break down on technology spending was typically distributed as follows: $62.4 \%$ on hardware, $12.1 \%$ on software, $6.3 \%$ on supplies, $6.2 \%$ on service, $4.9 \%$ on training, $2.8 \%$ on on-line services, and $5.3 \%$ on miscellaneous items. 
Heaviside (1995) stated that funding was the primary inhibitor to the use of technology in schools. He suggested that many school districts began the process of integrating computers into the classroom without a realistic financial plan. The success of the overall process of computer integration depended upon the involvement of all stakeholders, specifically teachers, in decisions such as the purchase of hardware and software.

When technology planning was being conducted without input from faculty, often the result was that the traditional curriculum and delivery process continued to be used and that the new technology was set aside (Burnell, 1994). Software Publishers (1992) reported that schools had spent more than 2.7 billion dollars on computer hardware and software, yet few revision plans included input from the users. The lack of teacher involvement in the purchase of the hardware and software became a major inhibitor to any computer integration plans. Hammond, et al. (1992) also stated that the lack of a long-term plan for technical support acted as a major inhibitor.

$\underline{\text { Telephobia }}$

Psychological inhibitors are silent inhibitors related to a lack of teacher involvement in computer technology plans (Lane, 1995). These psychological inhibitors were not usually considered in the technology plan and often acted as major silent inhibitors to the process. Lane (1995) coined the word "telephobia" and defined it as a general suspicion that change involving technology would replace teachers. Lane suggested, if this phenomena remained unanswered it would grow to be a major inhibitor to the computer integration process. Baugh (1994) also indicated that many teachers openly resisted computer technology integration into the classroom curriculum.

Many school districts in America at the close of the $20^{\text {th }}$ century saw reform. Reformers indicated that there was little doubt that computer integration into the classroom curriculum had and would continue to play a major role in the education 
reform process. If this was an accurate statement, then it must also be true that identifying inhibitors to this process was imperative and that appropriate action had be taken to eradicate these inhibitors.

\section{Summary}

This section of the literature review was directed to investigating and identifying inhibitors to the computer integration process. The results of this review of research identified twenty inhibitors. The following were found to be the ten primary inhibitors to the computer integration process.

1) The lack of training for teachers, administrators, and students. (Bolton, 1994), (Shoemaker, 1997), (Rapp, 1997),(Willis, 1994), (Kearsley and Lynch, 1994), (Harvey, 1990). These authors all agreed that the lack of training for those identified has proven to be a major inhibitor to integrating computers into the classroom curriculum. As of 1996, only $4.9 \%$ of each dollar spent on technology integration was spent for training and staff development (Bushweller, 1996).

2) The lack of access to computers for use in the classroom (Rapp, 1997), (Brickner, 1995), (Shoemaker, 1995), (Bolton, 1994), (Burnell, 1994), (Hammond, 1992). The authors believed that without the availability of computers and other resources, such as software, and the access to technical support, the teachers tended to return to past instructional models and lose their enthusiasm for implementing computer technology into the classroom curriculum.

3) Lack of support in the form of a long-term plan, and a lack of teacher involvement in the construction of the plan (Bricker, 1995), (Shoemaker, 1995), (Terrell, 1995), (Bolton, 1994).

4) Lack of a financial plan. (Heaviside, 1995), (Shoemaker, 1995), (Bolton, 1994), (Kearsley and Lynch, 1994) Identified by the authors as a major inhibitor 
to the failure of a successful computer integration plan for most school districts, large or small. Poor financial planning affected all other elements of the computer technology integration plan.

5) Lack of time for teachers to learn how to use computer technology in designing meaningful educational activities, and how to incorporate this new technology into the classroom curriculum (Owens, 1995), (Shoemaker, 1995).

6) Poor teacher attitude to the resistance to change and a lack of motivation of teachers (Scheidler, 1994), (Bolton, 1994), (Lane, 1995), (Kearsley and Lynch, 1994).

7) Lack of teacher involvement in selecting appropriate hardware and software. (Brichner, 1995), (Kearsley and Lynch, 1994), (Willis, 1994), Bushweller (1996) reported that $68.7 \%$ of each dollar was spent on hardware and software.

Decisions regarding such expenditures were most often made without the aid of those that would be using the hardware and software, i.e., teachers.

8) Lack of follow up training for teachers, including the lack of coaching and peer review (Brichner, 1995), (Willis, 1994).

9) Lack of an instructional model for teachers to maximize the use of computer technology (Brichner, 1995).

10) Lack of skills in using computers, a lack of information on how TO incorporate computer skills into the classroom curriculum, and a lack of computers in the classroom (Owens, 1995), (Rapp, 1997), (Brickner, 1995). 
The identified issue was not one of identifying these inhibitors and "alleviating" them, but rather, comprehending why these inhibitors were minimizing the success of the computer integration process. Through this process of understanding care must be taken to not eliminate one inhibitor only to create another.

Part Three: Enhancers to Integrating Computer Technology in K-12 Rural School Districts.

$\underline{\text { Introduction }}$

Part Two of this research investigated and identified the inhibitors to integrating computers into the classroom curriculum. Part Three investigated and identified the enhancers to the computer integration process. Computer integration into the classroom was not a new innovation. Seidel and Perez (1994) showed that computers have been used in education and training for more than thirty years

\section{Adoption of an Innovation}

Emery and Oeser (1958) stated that innovations were often not quickly adopted even when there was proof that there was little risk and much to gain in employing the innovation. The example used was a scenario that included adopting a new hybrid corn seed. The innovation had little risk and great benefit since this new seed would increase the quality and quantity of corn per acre. Some farmers seeing the results of the study adopted the new seed. However, more than ten years passed before the majority of farmers adopted the new hybrid seed; others have never adopted the hybrid corn seed. Marcinkiewicz 
(1993) concluded that Emery and Oeser saw the hesitation to adopt computers in the classroom as an analogous situation. Marcinkiewicz suggested that people were not willing to accept and use an innovation even when the innovation had promised to make a task easier and others had success with the innovation.

Terrell (1995) also suggested that teachers must be involved for the adoption of computer technology into the classroom curriculum to be successful. Campoy (1992) suggested that computer technology promises to help learners to be better problem solvers and to be better prepared for the twenty-first century workplace. Marcinkiewicz (1993) agreed with Terrell and suggested that full integration of computers into the classroom curriculum is, at best, a long way off, unless teachers who have access to computers begin to utilize them in the classroom curriculum. Marcinkiewicz's findings show that in the early 1990s, teachers with accessibility to computers were not using them in the classroom.

Without computer technology, the students, teachers, and the community would become isolated from the global community (Marcinkiewicz, 1993). Rogers (1995) defined innovation as an idea, practice, or object that was believed to be new by an individual or another unit of adoption. Based on Rogers' definition, integrating computers into the classroom curriculum, was a new idea, practice or object for many school districts. 


\section{Enhancers to the Integration Process}

As identified previously, Campoy (1992) believed that computer technology promised to assist students to become better problem solvers in the 21st century. However, Campoy also believed that this would only happen provided computer technology was used to create innovative practices for personalized instruction rather than using computer technology to supplement old lesson plans. Cuban (1992) and Sheingold (1991) believed that technology was a valuable catalyst for educational reform, and schools needed to recognize computer technology as a necessary component of educational reform. Sheingold (1991) also believed that the 1990's would bring together three vital elements for school reform: 1) an agreement about learning and teaching, 2) a significant effort to promote school reform, and 3) a major move to promote the use of technology in the schools.

This review of the literature investigating possible enhancers to integrating computers into the classroom curriculum has highlighted a list of enhancers that aid a successful computer integration plan. Marcinkiewicz (1993) pointed out that teacher competence was directly related to a successful integration plan. Marcinkiewicz also identified teacher innovation as a primary enchancer. Martin's (1988) research identified 14 enhancers to successful computer integration into the classroom curriculum.

1) Broad-based support for fueled by public support.

2) Availability of information from early adopted school districts.

3) Comprehensive, centralized planning of the entire process. 
4) School district with relatively few layers of bureaucracy.

5) Provision of sufficient resources for hardware, software, staff development, curriculum development, and technical support.

6) Creation of the position of a district-wide computer coordinator.

7) Selection of uniform hardware and software that were compatible with the educational goals of the district.

8) Visibility and portability of the micro-computers.

9) Interactive nature of the micro-computers.

10) Decentralized decision-making regarding actual use of the innovation.

11) Support of the principals in each school.

12) Provision for adequate teacher training and incentives to innovate.

13) High level of participation of teachers in the development of materials and curriculum.

14) Enthusiasm of students for microcomputers.

The review of literature also indicated, "Student attitudes toward using computers are important indicators of their future use of computers in the instructional setting" (Hunt and Bohlin, 1993). Martin (1988) pointed out that the classroom teacher was the key element to the successful integration of computers into the classroom curriculum. Dupagne and Krendl (1992) agreed that "most teachers expressed a positive attitude toward the integration of computers into their classroom curriculum" only when "in-service and workshop training was designed to promote better coordination between teachers and administrators, and to improve the efficiency of instructional computer 
applications." A positive teacher and student attitude toward computers could be a most significant enhancer to the successful integration of computers into the classroom curriculum (Baack, Brown and Brown, 1991; Dupagne and Krendl, 1992; Hunt and Bohlin, 1993).

\section{Exemplary Computer-Using Teachers}

Becker (1994) agreed with Baack, Brown and Brown, (1991); Dupagne and Krendl, (1992); and Hunt and Bohlin, (1993) in valuing attitude and computer use in the classroom curriculum. Becker, a sociologist and Associate Professor of Education at the University of California, was the head research scientist at the Johns Hopkins Center for Social Organization of Schools. His research focused on investigating and identifying how exemplary computer-using teachers differ from other teachers. Becker found four factors that lead to understanding when exemplary computer-using teachers were likely to be present in a classroom. They were:

1) Collegiality among users.

2) School support for using computers for consequential activities.

3) Resources allocated to staff development and computer coordinator.

4) Small class size.

Becker (1994) also suggested that the exemplary computer-using teacher would be male and possess a liberal arts rather than an education degree. He admitted that additional research was needed to determine the status of computer-using teachers, and the status of students and whether they were attaining the competency levels expected from the Education Reform movement. 


\section{Difference in Attitude}

Hunt and Bohlin's (1993) research investigated the attitudes of students entering a computer course at the college level. The primary focus of the research was to determine if gender, age, or past computer experience had any effect on measures of student enjoyment using computers, computer anxiety, confidence level, and the student perceived usefulness of computers. The results of the research showed that previous computer experience endangered both a positive attitude toward computers and the elimination of student computer anxiety. Students with previous experience were more relaxed and performed better in class. Age and sex did not have a strong correlation with confidence or the ability to use the computer. Hunt and Bohlin's (1993) research did show a strong correlation between using computers for recreational purposes and student confidence in the ability to use the computer. The researchers also stated that their study concluded that teachers who were familiar with computers were more confident about using them for classroom instruction. Teachers who lacked confidence in computers may believe computers were very useful; however, they would not utilize them in the classroom for instruction. The primary enhancer in Hunt and Bohlin's research was the use of teacher training through in-service training and workshops. They argued that if teachers were trained, they would be confident. Thus, training would enhance the use of computers in the classroom curriculum. Dupagne and Krendl (1992) suggested that teacher and student attitudes toward computers were generally positive and 
that this attitude acted as a powerful catalyst in the success of a computer integration plan for a school district.

\section{$\underline{\text { Summary }}$}

The research indicated that a computer integration program required an action plan that included a review of needed activities, services, and training and an implementation. Marcinkiewicz (1993), Martin (1988), and Dupagne and Krendl(1991) suggested that students and teachers must feel competent. They suggested that competence could be gained through on-going training, support, and encouragement from one another. Martin (1988) concluded that the major enhancers to integrating computers into the classroom were:

1) Broad-based support fueled by public support.

2) Availability of information from early-adopted school districts.

3) Comprehensive centralized planning of the entire process.

4) The size of the school district with relatively few layers of bureaucracy.

5) Provision of sufficient resources for hardware, software, staff development, curriculum development, and technical support.

6) Creation of the position of a district-wide computer coordinator.

7) Selection of uniform hardware and software that were compatible with the educational goals of the district.

8) Visibility and portability of the micro-computers.

9) Interactive nature of the micro-computers.

10) Decentralized decision-making regarding actual use of the innovation.

11) Support of the principals in each school. 
12) Provision for adequate teacher training and incentives to innovate.

13) High level of participation of teachers in the development of materials and curriculum.

14) Enthusiasm of students for microcomputers.

Martin concluded by emphasizing that the key to a successful computer integration program was and will continue to be the classroom teacher.

Marcinkiewicz (1993), Martin (1988), Dupagne and Krendl (1991), Baack, Brown, and Brown (1992), and Hunt and Bohlin, (1993) proposed that innovativeness was an important enhancer. They also agreed that innovativeness or willingness to change would open the process for integrating computers into the classroom. Becker (1994) suggested that exemplary computer using teachers required an environment that offered the opportunity to use computers and on-going training, and made time available to meet with other teachers and discuss strategies. Becker also suggested that small classes would enhance the interaction among teachers and between teacher and student. Hunt and Bohlin (1993), Becker (1994), Baack, Brown and Brown (1991), Marcinkiewiz (1993), and Martin (1988) all agreed that on-going teacher training was a primary enhancer to a successful computer integration plan. They further suggested that a poor plan for on-going teacher training in the areas of curriculum design, computer skills, and software selection would result in longterm challenges and the possibility of failure of the overall integration plan.

This literature review identified 19 possible enhancers to integrating computers into the classroom curriculum. Therefore, the first step for each 
school district, small or large is to identify district-specific enhancers and inhibitors to computer integration and develop an appropriate plan to meet the identified needs. 


\section{Part Four Research Design Matrix}

Below is a review of the individual research studies that were identified during this literature review. The matrix was designed to identify each of the research studies, subjects, research design, data collection, data analysis, and results for easy review (see Table 2).

\section{Table 2}

Research Designs

\begin{tabular}{|c|c|c|c|c|c|c|}
\hline AUTHOR & $\begin{array}{l}\text { Baugh } \\
(1994)\end{array}$ & $\begin{array}{l}\text { Becker } \\
\text { (1994) }\end{array}$ & $\begin{array}{l}\text { Davenport } \\
\text { (1995) }\end{array}$ & $\begin{array}{l}\text { Dupagne \&Krendl } \\
\text { (1992) }\end{array}$ & $\begin{array}{l}\text { Hunt \& Bohlin } \\
\text { (1993) }\end{array}$ & $\begin{array}{l}\text { Marcinkiewicz } \\
\text { (1993) }\end{array}$ \\
\hline SUBJECTS & $\begin{array}{l}10 \text { Secondary } \\
\text { teachers, all } \\
\text { female from a } \\
\text { rural school } \\
\text { district in WV. }\end{array}$ & $\begin{array}{l}1,029 \text { teachers } \\
\text { from grades } 3- \\
12, \text { who teach } \\
\text { academic } \\
\text { subjects }\end{array}$ & $\begin{array}{l}325 \text { educators } \\
\text { K-12 } \\
\text { Tennessee } \\
\text { schools, who } \\
\text { have completed } \\
\text { internet training, } \\
198 \text { responded. }\end{array}$ & $\begin{array}{l}1000 \text { teachers } \\
\text { teaching K-12 } \\
\text { in the US. }\end{array}$ & $\begin{array}{l}518 \text { college } \\
\text { education } \\
\text { major students, } \\
\text { mean age of } \\
32.3 \text { years }\end{array}$ & $\begin{array}{l}170 \text { teachers } \\
\text { K-12 from four } \\
\text { different school } \\
\text { districts. }\end{array}$ \\
\hline $\begin{array}{l}\text { RESEARCH } \\
\text { DESIGN }\end{array}$ & Descriptive & Investigative & Descriptive & Descriptive & Descriptive & Descriptive \\
\hline DATA COLLECTION & $\begin{array}{l}\text { Use of the } \\
\text { Concerns } \\
\text { Based } \\
\text { Adoption } \\
\text { model } \\
\text { (CBAM) } \\
\text { given twice } \\
\text { wk } 1 \text { \& wk } 8\end{array}$ & $\begin{array}{l}\text { I.E.A. comp } \\
\text { survey, } \\
\text { subject } \\
\text { specific } \\
\text { questionnaire } \\
\text { (four parts) }\end{array}$ & $\begin{array}{l}\text { Survey } \\
\text { questionnaire } \\
\text { Instrument } \\
\text { developed by } \\
\text { author, } 23 \text { item } \\
\text { Likert type } \\
\text { scale }\end{array}$ & $\begin{array}{l}\text { Self administered } \\
\text { questionnaires, } \\
\text { individual } \\
\text { interviews, } \\
\text { classroom } \\
\text { observations, } \\
\text { Case study, } \\
\text { Teacher Attitudes } \\
\text { of Instructional } \\
\text { Technology and } \\
\text { The Educational } \\
\text { Computing } \\
\text { survey(standardiz } \\
\text { ed test) } \\
\end{array}$ & $\begin{array}{l}\text { Computer } \\
\text { Attitude Scale } \\
\text { (CAS), } 40 \text { item } \\
\text {, } 4 \text { point Likert } \\
\text { type scale }\end{array}$ & $\begin{array}{l}\text { Level of Use } \\
\text { assessment, } \\
\text { (LU),Innovative } \\
\text { ness scale (IS), } \\
\text { and Teacher } \\
\text { Locus of } \\
\text { control scale } \\
\text { (TLC)., } \\
\text { assessment of } \\
\text { self- } \\
\text { competence, } \\
\text { assessment of } \\
\text { perceived } \\
\text { relevance. }\end{array}$ \\
\hline "DATA ANALYSIS & Percentiles & $\begin{array}{l}\text { Multiple } \\
\text { regression } \\
\text { analysis }\end{array}$ & $\begin{array}{l}\text { Chi-square and } \\
\text { Mann-WhitneyU } \\
\text { statistical test }\end{array}$ & $\begin{array}{l}\text { Observation and } \\
\text { interpretation, } \\
\text { Multiple } \\
\text { regression } \\
\text { analysis }\end{array}$ & $\begin{array}{l}\text { Multiple } \\
\text { regression } \\
\text { analysis, } \\
\text { correlation } \\
\text { analysis }\end{array}$ & $\begin{array}{l}\text { Descriptive } \\
\text { statistics, } \\
\text { Regression } \\
\text { Analysis, } \\
\text { logistic } \\
\text { regression, } \\
\text { intercorrelation } \\
\text { s } \\
\end{array}$ \\
\hline RESULTS & $\begin{array}{l}\text { Internet is a } \\
\text { valuable } \\
\text { classroom tool } \\
\text { Must have } \\
\text { training and } \\
\text { tech support }\end{array}$ & $\begin{array}{l}\text { Four factors } \\
\text { that embrace } \\
\text { the } \\
\text { environment } \\
\text { for exemplary } \\
\text { computer } \\
\text { using teachers }\end{array}$ & $\begin{array}{l}\text { Those who } \\
\text { have had } \\
\text { training are } \\
\text { using Internet. } \\
\text { Significant } \\
\text { difference } \\
\text { between } \\
\text { teachers who } \\
\text { use in class as } \\
\text { it relates to } \\
\text { beliefs. }\end{array}$ & $\begin{array}{l}\text { Teachers have a } \\
\text { positive attitude } \\
\text { about technology } \\
\text { but also have } \\
\text { concerns about } \\
\text { hardware and } \\
\text { software. Also } \\
\text { concerned about } \\
\text { not having the } \\
\text { opportunity for } \\
\text { adequate training. }\end{array}$ & $\begin{array}{l}\text { Previous } \\
\text { computer } \\
\text { experience } \\
\text { correlates with } \\
\text { a positive } \\
\text { student attitude } \\
\text { toward the use } \\
\text { of computers. }\end{array}$ & $\begin{array}{l}\text { Teachers are } \\
\text { under utilizing } \\
\text { computers in } \\
\text { the classroom. } \\
\text { Full integration } \\
\text { of computers } \\
\text { will occur when } \\
\text { teachers needs } \\
\text { and wants are } \\
\text { identified and } \\
\text { understood. }\end{array}$ \\
\hline
\end{tabular}


Reviewing the research allowed the researcher opportunity to view the various methods other researchers used to support their hypothesis. It was apparent that all six studies in the matrix have some correlation to the needs of this research project. 


\section{CHAPTER III}

\section{Methods}

The purpose of this research was to identify and analyze the factors that act as inhibitors and enhancers to implementing computer technology into the classroom curriculum of a small rural school district. This chapter includes a description of the study, research design, and selection of subjects; and a description of the survey instrument, data collection procedures, and the data analysis procedures.

\section{Description of the Study}

The purpose of this research study was to provide school board members, school administrators, and teachers with information required when developing a successful plan for integrating computer technology into the classroom curriculum. Descriptive data were collected in order to answer the research questions: 1) Were there differences among the positions of teachers, school administrators, and school board members regarding enhancers and inhibitors to the process of integrating computers into the classroom curriculum? 2) Were there differences between school districts regarding their opinion of enhancers and inhibitors to the process of integrating computers into the classroom curriculum?

The survey instrument was developed in the form of a six-point Likert scale to collect the necessary data. The data collected were used to answer 
the research questions and develop recommendations for the integration of computers into the classroom curriculum of a rural school district.

\section{$\underline{\text { Research Design }}$}

The overriding consideration in developing this research design was to answer the two research questions in Chapter One. This study used inferential and parametric statistics (two-way analysis of variance) to compare how the groups responded to the enhancers and inhibitors related to this study. The statistical program used was the S-Plus program. "S-Plus is the only Language created specifically for data visualization and exploration, statistical modeling, and programming with data" (Hinrichs, 1999, p. 3). The post-hoc analysis statistic used was the Fischer's Least Significant Difference Test.

\section{Selection of Subjects}

Three groups of subjects participated in the study. The literature review identified teachers, school administrators, and school board members as important elements in the integration of computers into the classroom curriculum. Each school district had nine school board members that were elected by the community in a general election. These board members represent the community and serve a four-year term. According to McKenze (1993) school boards are a primary factor to the process of computer integration because of their control of the finances, as was confirmed in the 
Annenberg Institute report on school reform (Kimpton and Sharp,1997). It was anticipated the results would provide indication of the important areas to be focused on to expedite the computer integration process.

Teachers $(\mathrm{N} 1=81)$ participating in this study included those at the 7-12 grade level from Turkeyfoot Valley Area School District, Rockwood School District, and Myersdale School District were participants in the project. The administrators ( $\mathrm{N} 2=9$ ) participating in this study were from Turkeyfoot Valley Area School District, Rockwood School District, Myersdale School District . School Board members $(\mathrm{N} 3=27)$ participating in this study were from Turkeyfoot Valley Area School District, Rockwood School District, and Myersdale School District.

The three groups of subjects were selected from school districts located in Somerset County, Pennsylvania, on the southernmost border of western Pennsylvania, sixty-nine miles southeast of Pittsburgh, Pennsylvania. The criteria for the selection of these three school districts were that they were involved in education reform, were integrating computers into the classrooms, and were similar in regard to financial challenges, population, unemployment, building renovation, and geographic location. The three school districts were approximately fifteen miles from each other. A comparison of the demographics of each school district may be found in Table 3. 
Table 3

Demographics Chart

\begin{tabular}{|c|c|c|c|}
\hline Area of Interest & Turkeyfoot & Myersdale & Rockwood \\
\hline Teachers (7-12) & 17 & 37 & 27 \\
\hline Administrators & 3 & 3 & 3 \\
\hline $\begin{array}{c}\text { School Board } \\
\text { Members }\end{array}$ & 9 & 9 & 5125 \\
\hline $\begin{array}{c}\text { Community } \\
\text { Population }\end{array}$ & 1992 & 9277 & $\$ 40,676.00$ \\
\hline $\begin{array}{c}\text { Average Teacher } \\
\text { Salary }\end{array}$ & $\$ 30,882.00$ & $\$ 37,810.00$ & 480 \\
\hline $\begin{array}{c}\text { Student Enrollment (7- } \\
12)\end{array}$ & 226 & $\$ 20,524.00$ & $\$ 21,306.00$ \\
\hline $\begin{array}{c}\text { Average Annual } \\
\text { Median Income } \\
\text { Per Family Unit }\end{array}$ & $\$ 15,820.00$ & $15 \%$ & $13 \%$ \\
\hline Unemployment & $20 \%$ & & \\
\hline
\end{tabular}

\section{$\underline{\text { Instrumentation }}$}

The instrument used in this study was designed as a six-point Likertscale. The main advantage of the Likert scale lies in the greater variance that can be obtained. The disadvantage is the vulnerability of this variance to biasing response sets, such as the over-rater or the under-rater. Although the five-point scale is most common, this Likert scale instrument was designed with a six-point scale. It permitted a greater variability and forced the respondents into a decision. Each statement was assigned a scale value indicating the strength of the respondent's attitude for an agreement response to the statement. The two Likert surveys were designed in value as follows: a value of (1.0) indicates the respondent strongly agrees with the item. A value of (6.0) indicates that the respondent strongly disagrees with the item. Therefore, the lower the score the more the respondent agrees with the item.

The statements in the scale were assumed to be equal. The two Likert scales used in this research were the same in design. Likert scale (1) focused 
on nineteen statements (enhancers) to the integration of computers into the classroom (see Appendix A). Likert scale (2) focused on twenty-one statements (inhibitors) to the integration of computers into the classroom curriculum (see Appendix B). Each subject received a cover letter that explained how to complete the Likert scales, and that the amount of time required to complete them would vary between fifteen and twenty minutes each (see Appendix C).

\section{Data Collection Procedure}

The two Likert scales were delivered to the administrative office of each of the three School Districts for distribution by the administrative secretary. The subjects were asked to read the statements listed on the first Likert scale (enhancers) and identify from their perspectives the degree of importance each statement had regarding the impact on the integration of computers into the classroom curriculum.

The respondents were then asked to complete the second Likert scale (inhibitors) as they had the first by identifying the degree of impact each statement had to the integration of computers into the classroom curriculum. Included with the Likert scales was a cover letter explaining the nature of this study. The opportunity to win a fifty-dollar gift certificate was offered to those that participated in completing the surveys, provided they completed the demographic information sheet attached to the survey. 


\section{Data Analysis Procedures}

Data from the two Likert scales was analyzed using a two-way ANOVA. This two-way ANOVA (location X position) was performed on each item within the two Likert scales. The independent variables in this study were the groups of teachers, administrators, and school board members from the three school districts. The dependent variables were the forty statements that each of the three groups of subjects responded to on the Likert scales. The raw scores were used in the statistical analysis and a significance level of $p \geq .05$ was selected. The two-way ANOVA tested for differences between positions and school districts, as well as for interactions between these two variables. The post-hoc analysis of significance F-tests was performed using the Fischer's Least Significant Difference Test within a $p \geq .05$ level was selected. The statistical program used in this study was the S-Plus program.

\section{Summary}

This chapter presented the methodology and procedures used in this study. This chapter included a description of the study, research design, selection of subjects, description of the instrument used, data collection procedures, data analysis procedures. The results of these analyses are found in Chapter Four. 


\section{CHAPTER IV}

Analysis of Data

\section{$\underline{\text { Introduction }}$}

The purpose of this study was to identify and analyze the factors that acted as inhibitors or enhancers to integrating computer technology into the classroom curriculum of a small rural school district. The analysis of data was organized by the following section sub-headings: Section One contains the demographics and survey return statistics of the participants in this research; Section Two contains the analysis of data by position of responses to the survey of enhancers and inhibitors; Section Three contains the survey comparison results of the three districts' responses to the enhancer and inhibitors survey.

\section{Demographics}

The participants in this research consisted of teachers, administrators, and school board members from three small rural school districts located in Somerset County, Pennsylvania. Table 4 describes the distribution of each school district's population of junior and senior high school teachers, school administrators, and school board members. The first group consisted of a total of 81 teachers in grades 7 through 12 within all three districts. The second group was composed of 9 administrators from the three school districts. (Table 4). The third group consisted of a total of 27 elected school board members from the three districts. 
Table 4

Demographics by District by Position

\section{District}

Turkeyfoot

Myersdale

Rockwood

Position

\begin{tabular}{lccc}
\hline Teacher (7-12) & 17 & 37 & 27 \\
\hline Administrator & 3 & 3 & 3 \\
\hline $\begin{array}{l}\text { School Board } \\
\text { Member }\end{array}$ & 9 & & \\
& 9 & 9 & 9 \\
\hline
\end{tabular}

The surveys contained 19-enhancer items and 21 -inhibitor items that were identified from the literature review. A score nearer 1.0 indicated that the person was in greater agreement with the item. The further the score varies from 1.0 the less in agreement with the item. Table 5 lists the number of surveys distributed at each school district and the total number of surveys returned by district and position. A total of 81 teacher surveys were sent out and 37 surveys were returned for a $45.6 \%$ return rate for teachers. A total of 9 administrator surveys were sent out, and 7 surveys were returned or a $77.7 \%$ return rate for administrators. A total of 27 school board member surveys were sent out, and 17 surveys were returned or a $62.9 \%$ return rate for the school board members. The total number of 117 surveys was distributed, and 61 were returned, resulting in a $51 \%$ return rate. 
Table 5

Survey Return Percentage Rate by District by Position

\begin{tabular}{|c|c|c|c|c|}
\hline District & Position & \# Sent & \# Returned & $\%$ Return Rate \\
\hline \multirow[t]{3}{*}{ Turkeyfoot } & Teacher & 17 & 16 & $90.4 \%$ \\
\hline & Administrator & 3 & 3 & $100 \%$ \\
\hline & School Board & 9 & 8 & $88.8 \%$ \\
\hline \multirow[t]{3}{*}{ Rockwood } & Teacher & 27 & 8 & $20.9 \%$ \\
\hline & Administrator & 3 & 2 & $66.6 \%$ \\
\hline & School Board & 9 & 4 & $44.4 \%$ \\
\hline \multirow[t]{3}{*}{ Myersdale } & Teacher & 37 & 13 & $35.1 \%$ \\
\hline & Administrator & 3 & 2 & $66.6 \%$ \\
\hline & School Board & 9 & 5 & $55.5 \%$ \\
\hline \multirow[t]{3}{*}{$\begin{array}{l}\text { Total \% All } \\
\text { By Position }\end{array}$} & Teacher & 81 & 37 & $45.6 \%$ \\
\hline & Administrator & 9 & 7 & $77.7 \%$ \\
\hline & School Board & 27 & 17 & $62.9 \%$ \\
\hline \multirow[t]{3}{*}{$\begin{array}{l}\text { Total \% All } \\
\text { By District }\end{array}$} & Turkeyfoot & 29 & 27 & $93.1 \%$ \\
\hline & Rockwood & 39 & 14 & $35.1 \%$ \\
\hline & Myersdale & 49 & 20 & $40.7 \%$ \\
\hline Grand Total & $\begin{array}{l}\text { All Districts/All } \\
\text { Positions }\end{array}$ & 117 & 61 & $51 \%$ \\
\hline
\end{tabular}

\section{$\underline{\text { Results of Research Questions }}$}

Research questions 1 and 2 were answered simultaneously using a two-way ANOVA. Question 1 stated: Were there differences among the positions of teachers, school administrators, and school board members regarding enhancers and inhibitors to the process of integrating computers into the classroom curriculum? Question 2 stated: Were there differences between school districts regarding their opinion of enhancers and inhibitors to the process of integrating computers into the classroom curriculum? 
The following analysis was completed on the 19-enhancer and 21inhibitor items for district and position. A two- way ANOVA (3x3), two factors at three levels of each district and position. When a significant difference at the $p \geq .05$ levels existed after the ANOVA was obtained a post-hoc analysis using the Fisher Least Significant Difference test was performed.

Survey Results of the Enhancer Items

The overall results to the enhancer survey items indicated that two of the 19-enhancer items yielded significant differences. The two-enhancer items (10 \& 18) were found to yield significance. Enhancer item 10 yielded significant difference of position. Enhancer item 18 yielded a significant interaction of position by district. Enhancer item 10 stated, "Decentralized decision-making regarding actual use of the innovation". The results indicated a significant difference of position. $F(2,52)=3.719, p \geq .05$ (Table $6 \mathrm{~A})$. A post-hoc analysis was completed using the Fishers LSD test, (Table 6B) which found differences between teachers and administrators as well as administrators and school board members. No significant differences were found between teachers and school board members.

Table 6A

Enhancer item 10

Two-way ANOVA Between Subjects (3X3)

\begin{tabular}{llcccl} 
Source & df & ss & ms & $F$ & $\operatorname{Pr}(F)$ \\
\hline District & 2 & 0.42394 & 0.211968 & 0.265888 & 0.7675611 \\
Position & 2 & 5.93116 & 2.965579 & 3.719957 & $0.0309068^{*}$ \\
ion: District & 4 & 4.45239 & 1.113099 & 1.396246 & 0.2481951
\end{tabular}

$\begin{array}{llll}\text { Error } & 52 & 41.45481 & 0.797208\end{array}$

* Indicates a significant difference at the $\mathrm{p} \geq .05$ level 
Table 6B

Enhancer item 10

$\underline{\text { Results of the Fisher's Least Significant Difference Test }}$

\begin{tabular}{lcc}
\multicolumn{1}{c}{ POSITION } & MEAN & DIFFERENCE \\
\hline Administration - School Board & $1.857-2.882$ & $1.025^{*}$ \\
Administration - Teachers & $1.857-2.811$ & $.954{ }^{*}$ \\
School Board - Teachers & $2.882-2.811$ & .071
\end{tabular}

* Indicates a significant difference at the $\mathrm{p} \geq .05$ level

Enhancer item 18 stated, "Innovativeness or willing to change". The two-way ANOVA results indicated that a significant interaction at the $F(4,52)$

$=2.83, p \geq .05$ level (Table 7). A significant interaction existed between administrators at Turkeyfoot School District and administrators at Myersdale school district, however, there was no difference between Turkeyfoot administrators and Rockwood school districts' administrators (Figure 1). Administrators at Turkeyfoot school district had a higher mean value indicating they had a more favorable opinion regarding enhancer item 18 than the administrators at Myersdale or Rockwood School Districts.

Table 7

Enhancer item 18

Two-way ANOVA (3X3)

\begin{tabular}{llcccc} 
Source & df & ss & ms & $F$ & $\operatorname{Pr}(F)$ \\
\hline District & 2 & 1.86635 & 0.933177 & 1.276559 & 0.2875926 \\
Position & 2 & 0.41517 & 0.207586 & 0.283972 & 0.7539475 \\
ion: District & 4 & 8.29614 & 2.074034 & 2.837219 & $0.0333832^{*}$
\end{tabular}

$\begin{array}{llll}\text { Error } & 52 & 38.01250 & 0.731010\end{array}$

*Indicates a significant difference at the $\mathrm{p} \geq .05$ level 


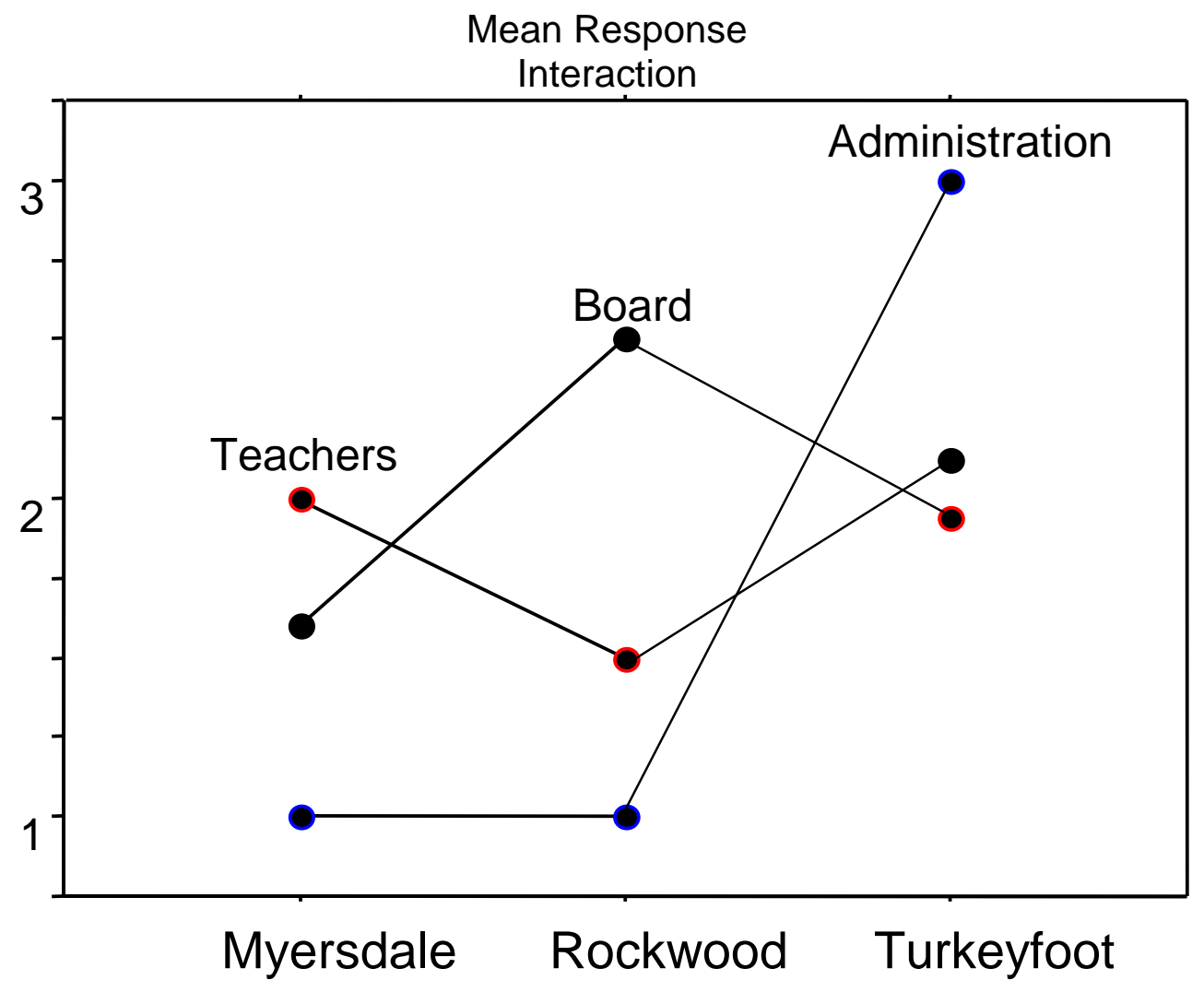

A complete listing of descriptive statistics including means, standard deviations and F-values of the 19-enhancer items can be found on Table 8. 


\section{Table 8 \\ Enhancer}

Means and SD between the three groups with F-Values Means and SD between the three School Districts with F-Values

*Indicates a significant difference existed and the Fischer Post-hoc Analysis test was performed (main effect)

$* *$ Indicates that a significant difference existed and the Fischer Post-hoc Analysis test was performed (interaction)

\begin{tabular}{|c|c|c|c|c|c|c|c|c|}
\hline Enhancer & Teacher & Administrator & $\begin{array}{c}\text { School } \\
\text { Board }\end{array}$ & $\begin{array}{c}\mathrm{F} \\
\text { Value }\end{array}$ & Turkeyfoot & Myersdale & Rockwood & $\begin{array}{c}\mathrm{F} \\
\text { Value }\end{array}$ \\
\hline Question & $\begin{array}{l}\text { Mean } \\
\text { SD }\end{array}$ & $\begin{array}{l}\text { Mean } \\
\text { SD }\end{array}$ & $\begin{array}{l}\text { Mean } \\
\text { SD }\end{array}$ & & $\begin{array}{l}\text { Mean } \\
\text { SD }\end{array}$ & $\begin{array}{l}\text { Mean } \\
\text { SD }\end{array}$ & $\begin{array}{l}\text { Mean } \\
\text { SD }\end{array}$ & \\
\hline $\begin{array}{l}\text { 1. Broad-base support fueled } \\
\text { by public support. }\end{array}$ & $\begin{array}{c}2.297 \\
.938\end{array}$ & $\begin{array}{c}2.142 \\
.690\end{array}$ & $\begin{array}{l}2.647 \\
1.114\end{array}$ & 1.080 & $\begin{array}{c}2.185 \\
.878\end{array}$ & $\begin{array}{l}2.500 \\
1.192\end{array}$ & $\begin{array}{l}2.571 \\
.755\end{array}$ & 0.995 \\
\hline $\begin{array}{l}\text { 2. Availability of information } \\
\text { from early-adopted school } \\
\text { districts. }\end{array}$ & $\begin{array}{c}2.513 \\
.869\end{array}$ & $\begin{array}{c}2.000 \\
.816\end{array}$ & $\begin{array}{l}2.764 \\
.970\end{array}$ & 1.765 & $\begin{array}{c}2.481 \\
.893\end{array}$ & $\begin{array}{l}2.600 \\
1.169\end{array}$ & $\begin{array}{c}2.500 \\
.854\end{array}$ & 0.104 \\
\hline $\begin{array}{l}\text { 3. Comprehensive centralized } \\
\text { planning of the entire process. }\end{array}$ & $\begin{array}{l}2.000 \\
1.000\end{array}$ & $\begin{array}{l}1.714 \\
.951\end{array}$ & $\begin{array}{l}2.411 \\
1.003\end{array}$ & 1.447 & $\begin{array}{c}2.259 \\
.902\end{array}$ & $\begin{array}{l}2.000 \\
1.169\end{array}$ & $\begin{array}{l}1.857 \\
.949\end{array}$ & 0.840 \\
\hline $\begin{array}{l}\text { 4. Size of the school district } \\
\text { with relatively few layers of } \\
\text { bureaucracy. }\end{array}$ & $\begin{array}{l}2.594 \\
1.235\end{array}$ & $\begin{array}{l}1.714 \\
.755\end{array}$ & $\begin{array}{l}2.294 \\
1.046\end{array}$ & 1.900 & $\begin{array}{c}2.074 \\
.997\end{array}$ & $\begin{array}{l}2.700 \\
1.341\end{array}$ & $\begin{array}{l}2.642 \\
1.081\end{array}$ & 2.177 \\
\hline $\begin{array}{l}\text { 5. Provision of sufficient } \\
\text { resources for hardware, } \\
\text { software, staff development } \\
\text { curriculum development and } \\
\text { technical support. }\end{array}$ & $\begin{array}{l}1.513 \\
.803\end{array}$ & $\begin{array}{l}1.428 \\
.786\end{array}$ & $\begin{array}{c}2.058 \\
.899\end{array}$ & 2.774 & $\begin{array}{c}1.777 \\
.891\end{array}$ & $\begin{array}{c}1.600 \\
.820\end{array}$ & $\begin{array}{l}1.500 \\
.854\end{array}$ & 0.588 \\
\hline $\begin{array}{l}\text { 6. Creation of the position of a } \\
\text { district-wide computer } \\
\text { coordinator. }\end{array}$ & $\begin{array}{l}1.918 \\
1.210\end{array}$ & $\begin{array}{l}2.000 \\
1.154\end{array}$ & $\begin{array}{l}2.294 \\
.919\end{array}$ & 0.548 & $\begin{array}{l}2.333 \\
1.208\end{array}$ & $\begin{array}{c}1.700 \\
.864\end{array}$ & $\begin{array}{l}1.928 \\
1.206\end{array}$ & 1.865 \\
\hline $\begin{array}{l}\text { 7. Selection of uniform } \\
\text { hardware and software that was } \\
\text { compatible with the } \\
\text { educational goals of the } \\
\text { district. }\end{array}$ & $\begin{array}{l}2.216 \\
1.157\end{array}$ & $\begin{array}{c}1.857 \\
.899\end{array}$ & $\begin{array}{l}2.058 \\
.966\end{array}$ & 0.478 & $\begin{array}{l}2.333 \\
1.143\end{array}$ & $\begin{array}{l}1.800 \\
.951\end{array}$ & $\begin{array}{l}2.214 \\
1.050\end{array}$ & 1.518 \\
\hline $\begin{array}{l}\text { 8. Visibility and portability of } \\
\text { the computers. }\end{array}$ & $\begin{array}{l}2.594 \\
1.403 \\
\end{array}$ & $\begin{array}{l}1.857 \\
.690\end{array}$ & $\begin{array}{l}2.647 \\
.606\end{array}$ & 1.212 & $\begin{array}{l}2.740 \\
1.227\end{array}$ & $\begin{array}{l}2.400 \\
1.231\end{array}$ & $\begin{array}{c}2.285 \\
.994\end{array}$ & 0.836 \\
\hline $\begin{array}{l}\text { 9. Interactive nature of the } \\
\text { computers. }\end{array}$ & $\begin{array}{l}2.270 \\
1.216 \\
\end{array}$ & $\begin{array}{l}1.428 \\
.786\end{array}$ & $\begin{array}{l}2.470 \\
.799 \\
\end{array}$ & 2.222 & $\begin{array}{l}2.481 \\
1.122 \\
\end{array}$ & $\begin{array}{l}2.200 \\
1.105 \\
\end{array}$ & $\begin{array}{c}1.785 \\
.974\end{array}$ & 1.920 \\
\hline $\begin{array}{l}\text { 10. Decentralized decision- } \\
\text { making regarding actual use of } \\
\text { the innovation. }\end{array}$ & $\begin{array}{c}2.810 \\
.844\end{array}$ & $\begin{array}{l}1.857 \\
.690\end{array}$ & $\begin{array}{l}2.882 \\
1.053\end{array}$ & $3.719^{*}$ & $\begin{array}{l}2.814 \\
1.110\end{array}$ & $\begin{array}{l}2.650 \\
.745\end{array}$ & $\begin{array}{c}2.642 \\
.841\end{array}$ & 0.265 \\
\hline $\begin{array}{l}\text { 11. Support of the principals in } \\
\text { each school. }\end{array}$ & $\begin{array}{c}2.027 \\
.970\end{array}$ & $\begin{array}{l}1.285 \\
.487\end{array}$ & $\begin{array}{l}2.117 \\
1.053\end{array}$ & 1.921 & $\begin{array}{c}1.884 \\
.951\end{array}$ & $\begin{array}{l}2.100 \\
1.071\end{array}$ & $\begin{array}{l}1.928 \\
.916\end{array}$ & 0.284 \\
\hline $\begin{array}{l}\text { 12. Provision for adequate } \\
\text { teacher training and incentives } \\
\text { to innovate. }\end{array}$ & $\begin{array}{l}1.648 \\
1.005\end{array}$ & $\begin{array}{l}1.285 \\
.487\end{array}$ & $\begin{array}{l}2.176 \\
.951\end{array}$ & 2.644 & $\begin{array}{c}1.740 \\
.902\end{array}$ & $\begin{array}{l}1.850 \\
1.136\end{array}$ & $\begin{array}{c}1.642 \\
.928\end{array}$ & 0.191 \\
\hline $\begin{array}{l}\text { 13. High level of participation } \\
\text { of teachers in the development } \\
\text { of materials and curriculum. }\end{array}$ & $\begin{array}{c}1.972 \\
.985\end{array}$ & $\begin{array}{c}2.000 \\
.816\end{array}$ & $\begin{array}{l}2.411 \\
.795\end{array}$ & 1.258 & $\begin{array}{c}2.148 \\
.948\end{array}$ & $\begin{array}{l}2.000 \\
1.025\end{array}$ & $\begin{array}{c}2.142 \\
.770\end{array}$ & 0.161 \\
\hline $\begin{array}{l}\text { 14. Enthusiasm of students for } \\
\text { computers }\end{array}$ & $\begin{array}{l}1.783 \\
.886 \\
\end{array}$ & $\begin{array}{l}1.714 \\
.951\end{array}$ & $\begin{array}{l}2.000 \\
.935 \\
\end{array}$ & 0.455 & $\begin{array}{c}1.703 \\
.912 \\
\end{array}$ & $\begin{array}{l}2.050 \\
.887\end{array}$ & $\begin{array}{c}1.785 \\
.892 \\
\end{array}$ & 0.876 \\
\hline $\begin{array}{l}\text { 15. Collegiality among all } \\
\text { users. }\end{array}$ & $\begin{array}{l}2.837 \\
1.142\end{array}$ & $\begin{array}{c}2.142 \\
.690\end{array}$ & $\begin{array}{l}2.764 \\
.831\end{array}$ & 1.452 & $\begin{array}{c}3.037 \\
.979\end{array}$ & $\begin{array}{l}2.350 \\
.9333 \\
\end{array}$ & $\begin{array}{l}2.714 \\
1.138 \\
\end{array}$ & 2.594 \\
\hline $\begin{array}{l}\text { 16. School support for using } \\
\text { computers for consequential } \\
\text { activities. }\end{array}$ & $\begin{array}{l}2.459 \\
.767\end{array}$ & $\begin{array}{l}1.857 \\
.899\end{array}$ & $\begin{array}{l}2.588 \\
.712\end{array}$ & 2.154 & $\begin{array}{c}2.481 \\
.849\end{array}$ & $\begin{array}{l}2.500 \\
.688\end{array}$ & $\begin{array}{l}2.214 \\
.801\end{array}$ & 0.670 \\
\hline 17. Small class size. & $\begin{array}{l}1.972 \\
1.142 \\
\end{array}$ & $\begin{array}{c}2.571 \\
.786\end{array}$ & $\begin{array}{l}2.529 \\
1.067 \\
\end{array}$ & 1.824 & $\begin{array}{l}2.185 \\
1.241 \\
\end{array}$ & $\begin{array}{c}2.000 \\
.917\end{array}$ & $\begin{array}{l}2.500 \\
1.091 \\
\end{array}$ & 0.860 \\
\hline $\begin{array}{l}\text { 18. Innovativeness or willing to } \\
\text { change. }\end{array}$ & $\begin{array}{l}1.864 \\
.887\end{array}$ & $\begin{array}{l}1.857 \\
.069\end{array}$ & $\begin{array}{l}2.058 \\
.899\end{array}$ & $0.283^{* *}$ & $\begin{array}{c}2.111 \\
.847\end{array}$ & $\begin{array}{l}1.800 \\
.951\end{array}$ & $\begin{array}{c}1.714 \\
.913\end{array}$ & 1.276 \\
\hline $\begin{array}{l}\text { 19. Assisting teachers and } \\
\text { students in feeling competent. }\end{array}$ & $\begin{array}{c}2.162 \\
.957\end{array}$ & $\begin{array}{l}1.714 \\
.951\end{array}$ & $\begin{array}{l}2.058 \\
1.028\end{array}$ & 0.596 & $\begin{array}{l}2.185 \\
1.039\end{array}$ & $\begin{array}{c}2.100 \\
.967\end{array}$ & $\begin{array}{c}1.857 \\
.864\end{array}$ & 0.538 \\
\hline
\end{tabular}




\section{Survey Results of the Inhibitors Items}

The Inhibitor item survey two-way ANOVA results indicated that there were 10 inhibitor items that yielded significant $F$-values at the $p \geq .05$ level with no interactions. The Post-hoc Fishers' Least Significant Difference Test was conducted to determine where the differences occured. Inhibitor items 3, 4, 6, $9,11,12,13,18$, and 20 yielded a significant difference of position. However, inhibitor item 19 yielded a significant difference by school district Inhibitor item 3 was "Inadequate financial planning." The two-way ANOVA indicated a significant main effect of position $F(2,52)=4.13, p \geq .05$ (Table 9A). The Fishers' Least Significant Difference test indicated that administrators had significantly lower scores or more favorable opinion than did board members and teachers, but no differences were found between school board members and teachers (Table 9B).

Table 9A Inhibitor item 3

Two-way ANOVA Between Subjects (3X3)

\begin{tabular}{lllccl} 
Source & df & \multicolumn{1}{c}{ ss } & ms & F & \multicolumn{1}{c}{$\operatorname{Pr}(F)$} \\
\hline District & 2 & 1.42697 & 0.713485 & 0.744633 & 0.4800005 \\
Position & 2 & 7.91579 & 3.957896 & 4.130683 & $0.0217451^{*}$ \\
ion: District & 4 & 3.04057 & 0.760143 & 0.793328 & 0.5350065 \\
Error & 51 & 48.86667 & 0.958170 & &
\end{tabular}

*Indicates a significant difference at the $\mathrm{p} \geq .05$ level 
Table 9B

Inhibitor item 3

Results of the Fisher's Least Significant Difference Test

POSITION MEAN

DIFFERENCE

Administrator / School Board

Administrators / Teachers

$1.286-2.529$

$1.243^{*}$

School Board / Teachers

$1.286-2.305$

$1.019^{*}$

$2.529-2.305$

0.224

${ }^{*}$ Indicates a significant difference at the $\mathrm{p} \geq .05$ level

Inhibitor item 4 was "Teacher attitude." The ANOVA indicated a significant main effect of position $F(2,52)=7.1, p \geq .05(10 \mathrm{~A})$. The Fishers' Least Significant Difference test indicated that again administrators had significantly lower or more favorable scores than did teachers, but school board members did not differ significantly from either administrators or teachers.

Table $10 \mathrm{~A}$

Inhibitor item 4

Two-way ANOVA Between Subjects (3X3)

\begin{tabular}{llllll} 
Source & $\mathrm{df}$ & \multicolumn{1}{c}{$\mathrm{ss}$} & $\mathrm{ms}$ & $\mathrm{F}$ & $\operatorname{Pr}(\mathrm{F})$ \\
\hline District & 2 & 2.05581 & 1.027906 & 1.329682 & 0.2734059 \\
Position & 2 & 10.97961 & 5.489804 & 7.101522 & $0.0018761^{*}$ \\
ion: District & 4 & 5.78258 & 1.445644 & 1.870062 & 0.1296578 \\
Error & 52 & 40.19840 & 0.773046 & & \\
*Indicates a significant difference at the $\mathrm{p} \geq .05$ level &
\end{tabular}

Table 10B

Inhibitor item 4

Results of the Fisher's Least Significant Difference Test

POSITION MEAN DIFFERENCE

Administrator / School Board

$1.286-1.882$

0.596

Administrators / Teachers

$1.286-2.486$

$1.200^{*}$

School Board / Teachers

$1.882-2.486$

0.604

*Indicates a significant difference at the $\mathrm{p} \geq .05$ level 
Inhibitor item 6 was "'Lack of teacher's ability to design educational activities." The ANOVA indicated a significant main effect of position $F(2,52)=$ 4.19, $\mathrm{p} \geq .05$ (Table 11A). The Fishers' Least Significant Difference test indicated that administrators had significantly lower scores than did school board members and teachers, while teachers and school board members did not differ significantly from each other (Table11B).

Table $11 \mathrm{~A}$ Inhibitor item 6

Two-way ANOVA Between Subjects (3X3)

\begin{tabular}{lllccl} 
Source & df & \multicolumn{1}{c}{ ss } & ms & F & $\operatorname{Pr}(F)$ \\
\hline District & 2 & 2.03743 & 1.018716 & 0.783379 & 0.4621763 \\
Position & 2 & 10.91768 & 5.458840 & 4.197774 & $0.0204154^{*}$ \\
ion: District & 4 & 2.17751 & 0.544378 & 0.418619 & 0.7944574 \\
Error & 52 & 67.62147 & 1.300413 & &
\end{tabular}

*Indicates a significant difference at the $\mathrm{p} \geq .05$ level

Table 11B

Inhibitor item 6

Results of the Fisher's Least Significant Difference Test

POSITION MEAN DIFFERENCE

Administrator / School Board

$\begin{array}{ll}1.429-2.588 & 1.159^{*} \\ 1.429-2.811 & 1.382^{*} \\ 2.588-2.811 & 0.223\end{array}$

Administrators / Teachers

School Board / Teachers

$2.588-2.811$

0.223

*Indicates a significant difference at the $\mathrm{p} \geq .05$ level

Inhibitor item 9 was "Failure to develop a long term plan." The ANOVA indicated a significant main effect of position $F(2,52)=4.36, p \geq .01$ (Table 12A). Fishers' Least Significant Difference test indicated that administrators had significantly lower more favorable scores than did school board members and teachers. Teachers did not differ significantly from school board members (Table 12B). 
Table 12A

Inhibitor item 9

Two-way ANOVA Between Subjects (3X3)

\begin{tabular}{llllll} 
Source & df & \multicolumn{1}{c}{ ss } & ms & $F$ & $\operatorname{Pr}(F)$ \\
\hline District & 2 & 0.73769 & 0.368844 & 0.335057 & 0.7168299 \\
Position & 2 & 9.60453 & 4.802264 & 4.362370 & $0.0177247^{*}$ \\
tion: District & 4 & 2.18469 & 0.546172 & 0.496142 & 0.7385884 \\
Error & 52 & 57.24359 & 1.100838 & & \\
*Indicates a significant difference at the $\mathrm{p} \geq .01$ level &
\end{tabular}

Table 12B

Inhibitor item 9

Results of the Fisher's Least Significant Difference Test

POSITION MEAN

DIFFERENCE

Administrator / School Board

$\begin{array}{ll}1.571-2.765 & 1.194^{\star} \\ 1.571-2.811 & 1.240^{\star} \\ 2.765-2.811 & 0.046\end{array}$

Administrators / Teachers

School Board / Teachers

$2.765-2.811$

0.046

*Indicates a significant difference at the $\mathrm{p} \geq .01$ level

Inhibitor item 11 was "Lack of a plan." The ANOVA indicated a significant main effect of position $F(2,52)=4.03, p \geq .05$ (Table 13A). Fishers' Least

Significant Difference test indicated that administrators had significantly lower scores than did school board members and teachers. However, school board members did not differ significantly from teachers on this item (Table 13B).

Table 13A

Inhibitor item 11

Two-way ANOVA Between Subjects (3X3)

\begin{tabular}{lllccl} 
Source & df & \multicolumn{1}{c}{ ss } & ms & \multicolumn{1}{c}{$\mathrm{F}$} & \multicolumn{1}{c}{$\operatorname{Pr}(\mathrm{F})$} \\
\hline District & 2 & 0.61474 & 0.307368 & 0.240992 & 0.7867209 \\
Position & 2 & 10.28489 & 5.142444 & 4.031925 & $0.0235583^{\star}$ \\
ion: District & 4 & 1.92548 & 0.481370 & 0.377417 & 0.8237235 \\
Error & 52 & 66.32244 & 1.275431 & &
\end{tabular}

*Indicates a significant difference at the $\mathrm{p} \geq .05$ level 
Table 13B

Inhibitor item 11

$\underline{\text { Results of the Fisher's Least Significant Difference Test }}$

POSITION MEAN

DIFFERENCE

Administrator / School Board

$1.429-2.588$

$1.159^{*}$

Administrators / Teachers

$1.429-2.730$

$1.301^{*}$

School Board / Teachers

$2.588-2.730$

0.142

${ }^{*}$ Indicates a significant difference at the $\mathrm{p} \geq .05$ level

Inhibitor item 12 was "Selection of hardware and software." The ANOVA

indicated a significant main effect of position $F(2,52)=3.95, p \geq .05(14 A)$.

Fishers' Least Significant Difference test indicated that administrators had

significantly lower scores than did teachers, but no significant differences were

found between administrators and school board members, and school board

members and teachers (Table 14B).

Table 14A

Inhibitor item 12

Two-way ANOVA Between Subjects (3X3)

\begin{tabular}{lllccl} 
Source & df & \multicolumn{1}{c}{ ss } & ms & $F$ & $\operatorname{Pr}(F)$ \\
\hline District & 2 & 1.56848 & 0.784242 & 0.892223 & 0.4159230 \\
Position & 2 & 6.96122 & 3.480608 & 3.959847 & $0.0250771^{*}$ \\
ion: District & 4 & 1.82914 & 0.457286 & 0.520248 & 0.7211996 \\
Error & 52 & 45.70673 & 0.878976 & &
\end{tabular}

${ }^{*}$ Indicates a significant difference at the $\mathrm{p} \geq .05$ level 
Table 14B

Inhibitor item 12

Results of the Fisher's Least Significant Difference Test

POSITION MEAN

DIFFERENCE

Administrator / School Board

Administrators / Teachers

School Board / Teachers

$1.857-2.000$

0.143

$1.857-2.621$

$0.764^{\star}$

${ }^{*}$ Indicates a significant difference at the $\mathrm{p} \geq .05$ level

Inhibitor item 13 was "Lack of considering human resistance to change."

The ANOVA indicated a significant main effect of position $F(2,52)=4.58, p \geq .01$

(Table 15A). Fishers' Least Significant Difference test indicated that

administrators had significantly lower scores than did teachers, where as there

were no significant differences between administrators and school board

members, and school board members and teachers (Table 15B).

Table 15A

Inhibitor item 13

Two-way ANOVA Between Subjects (3X3)

\begin{tabular}{lllccl} 
Source & df & ss & ms & $F$ & \multicolumn{1}{c}{$\operatorname{Pr}(F)$} \\
\hline District & 2 & 3.45375 & 1.726874 & 1.629082 & 0.2059582 \\
Position & 2 & 9.72444 & 4.862220 & 4.586877 & $0.0146350^{*}$ \\
n: District & 4 & 2.61837 & 0.654593 & 0.617524 & 0.6519897 \\
Error & 52 & 55.12147 & 1.060028 & &
\end{tabular}

*Indicates a significant difference at the $p \geq .01$ level 
Table 15B

Inhibitor item 13

Results of the Fisher's Least Significant Difference Test

POSITION MEAN

DIFFERENCE

Administrator / School Board

Administrators / Teachers

$1.428-2.235$

0.807

School Board / Teachers

$1.428-2.703$

$1.275^{\star}$

${ }^{*}$ Indicates a significant difference at the $\mathrm{p} \geq .01$ level

0.468

Inhibitor item 18 was "Lack of motivation for teachers." The ANOVA indicated a significant main effect of position $F(2,52)=6.32 \mathrm{p} \geq .005$ (Table 16A).

Fishers' Least Significant Difference test was performed and indicated that administrators had significantly lower scores than did teachers, where as there were no significant differences between administrators and school board members, and school board members and teachers. Whereas, the difference between school board members and teachers was approaching significance (Table 16B).

Table 16A Inhibitor item 18

Two-way ANOVA Between Subjects (3X3)

\begin{tabular}{llllcl} 
Source & df & \multicolumn{1}{c}{ ss } & ms & $F$ & $\operatorname{Pr}(F)$ \\
\hline District & 2 & 4.69614 & 2.348072 & 1.722013 & 0.1889333 \\
Position & 2 & 17.23060 & 8.615301 & 6.318232 & $0.0035362^{*}$ \\
n: District & 4 & 4.71492 & 1.178730 & 0.864449 & 0.4916584 \\
Error & 51 & 69.54167 & 1.363562 & &
\end{tabular}

${ }^{*}$ Indicates a significant difference at the $\mathrm{p} \geq .005$ level 
Table 16B

Inhibitor item 18

$\underline{\text { Results of the Fisher's Least Significant Difference Test }}$

POSITION MEAN

DIFFERENCE

Administrator / School Board

$1.857-2.000$

0.143

Administrators / Teachers

$1.857-3.027$

$1.170^{*}$

School Board / Teachers

$2.000-3.027$

1.027

${ }^{*}$ Indicates a significant difference at the $\mathrm{p} \geq .05$ level

Inhibitor item 20 was "Lack of instructional model for teachers." The

ANOVA indicated a significant main effect of position $F(2,52)=3.52 p \geq .05$

(Table 18A). Fishers' Least Significant Difference test indicated that

administrators had significantly lower scores than did the teachers and school

board. Whereas, there was no significant difference between administrators and school board, and school board members and teachers (Table 18B).

Table 17A

Inhibitor item 20

Two-way ANOVA Between Subjects (3X3)

\begin{tabular}{lllccl} 
Source & df & ss & $\mathrm{ms}$ & $\mathrm{F}$ & $\operatorname{Pr}(\mathrm{F})$ \\
\hline District & 2 & 3.22233 & 1.611163 & 2.343069 & 0.1060934 \\
Position & 2 & 4.84351 & 2.421754 & 3.521889 & $0.0367756^{*}$ \\
ion: District & 4 & 3.98071 & 0.995178 & 1.447259 & 0.2317166 \\
Error & 52 & 35.75673 & 0.687629 & &
\end{tabular}

${ }^{*}$ Indicates a significant difference at the $\mathrm{p} \geq .05$ level 
Table 17B

Inhibitor item 20

Results of the Fisher's Least Significant Difference Test

POSITION MEAN

DIFFERENCE

Administrator / School Board

$1.570-2.117$

0.547

Administrators / Teachers

$1.570-2.459$

$0.889^{*}$

School Board / Teachers

$2.117-2.459$

0.342

${ }^{*}$ Indicates a significant difference at the $\mathrm{p} \geq .05$ level

Inhibitor item 19 was "Lack of teacher involvement in selecting hardware and software. "The ANOVA indicated a significant main effect by district $F(2,51)$

$=3.64 p \geq .05$. The Fishers' Least Significant Difference test indicated that Myersdale school district had significantly lower or more favorable scores than did the Turkeyfoot school district. However, there was no difference between the Myersdale and Rockwood school districts', or Turkeyfoot and Rockwood school districts'.

Table 18A

Inhibitor item 19

Two-way ANOVA Between Subjects (3X3)

\begin{tabular}{lllccc} 
Source & df & \multicolumn{1}{c}{ ss } & ms & $F$ & $\operatorname{Pr}(F)$ \\
\hline District & 2 & 6.72849 & 3.364245 & 3.646486 & $0.0330999^{*}$ \\
Position & 2 & 1.74124 & 0.870618 & 0.943658 & 0.3958911 \\
n: District & 4 & 1.46104 & 0.365261 & 0.395904 & 0.8106360 \\
Error & 51 & 47.05256 & 0.922599 & &
\end{tabular}

*Indicates a significant difference at the $\mathrm{p} \geq .05$ level 
Table 18B

Inhibitor item 19

Results of the Fisher's Least Significant Difference Test

DISTRICT MEAN

DIFFERENCE

Myersdale / Rockwood

Myersdale / Turkeyfoot

Rockwood / Turkeyfoot

$2.050-2.460$

0.410

$1.286-2.814$

$0.764^{*}$

${ }^{*}$ Indicates a significant difference at the $\mathrm{p} \geq .05$ level

A complete list of the descriptive statistics of the inhibitor items including the means, standard deviations by position and district can be seen on table 19 .

\section{$\underline{\text { Summary }}$}

There was a high rate of agreement between the literature review and the three positions, and three school districts on which enhancer and inhibitor items were helpful or not helpful to the integration of computers into the classroom. Research questions 1 and 2 were answered simultaneously using a two-way ANOVA. Two enhancer items were found to have significant differences at the $p \geq .05$ level. The first enhancer item 10 yielded a significant main effect of position that indicated that teachers and administrators differed while no significant difference was found between teachers and school board members. The second enhancer item 18, yielded a interaction of position as a function of district indicating the administrators at Turkeyfoot School District had significantly higher mean values than Rockwood or Myersdale School Districts. Ten inhibitor items yielded a significant difference. 
Table 19

Inhibitor

*Indicates a significant difference existed and the Fischer Post-hoc Analysis test was performed to determine the differences (main ffect) **Indicates a significant difference existed and the Fischer Post-hoc Analysis test was performed to determine the differences(interaction)

\begin{tabular}{|c|c|c|c|c|c|c|c|c|}
\hline Inhibitor & Teacher & Administrator & $\begin{array}{l}\text { School } \\
\text { Board }\end{array}$ & $\begin{array}{c}\mathrm{F} \\
\text { Value }\end{array}$ & Turkeyfoot & "Myersdale & "Rockwood & $\begin{array}{c}\mathrm{F} \\
\text { Value }\end{array}$ \\
\hline Question & $\begin{array}{l}\text { Mean } \\
\text { SD }\end{array}$ & $\begin{array}{l}\text { Mean } \\
\text { SD }\end{array}$ & $\begin{array}{l}\text { Mean } \\
\text { SD }\end{array}$ & & $\begin{array}{l}\text { Mean } \\
\text { SD }\end{array}$ & $\begin{array}{l}\text { Mean } \\
\text { SD }\end{array}$ & $\begin{array}{l}\text { Mean } \\
\text { SD }\end{array}$ & \\
\hline $\begin{array}{l}\text { 1. Lack of strong } \\
\text { leadership. }\end{array}$ & $\begin{array}{l}2.513 \\
1.121\end{array}$ & $\begin{array}{l}2.000 \\
1.000\end{array}$ & $\begin{array}{c}2.235 \\
.831\end{array}$ & 1.116 & $\begin{array}{c}2.296 \\
.912\end{array}$ & $\begin{array}{l}2.200 \\
1.005\end{array}$ & $\begin{array}{l}2.785 \\
1.251\end{array}$ & 1.670 \\
\hline $\begin{array}{l}\text { 2. Lack of appropriate } \\
\text { training for teachers, } \\
\text { administrators, and } \\
\text { students. }\end{array}$ & $\begin{array}{l}2.162 \\
1.116\end{array}$ & $\begin{array}{c}1.428 \\
.534\end{array}$ & $\begin{array}{l}1.823 \\
1.074\end{array}$ & 1.772 & $\begin{array}{l}1.962 \\
1.018\end{array}$ & $\begin{array}{c}1.700 \\
.978\end{array}$ & $\begin{array}{l}2.428 \\
1.342\end{array}$ & 1.800 \\
\hline $\begin{array}{l}\text { 3. Inadequate financial } \\
\text { planning. }\end{array}$ & $\begin{array}{c}2.305 \\
.980\end{array}$ & $\begin{array}{c}1.285 \\
.487\end{array}$ & $\begin{array}{l}2.529 \\
1.067\end{array}$ & $4.130^{*}$ & $\begin{array}{l}2.407 \\
1.009\end{array}$ & $\begin{array}{l}2.052 \\
1.025\end{array}$ & $\begin{array}{l}2.214 \\
1.050\end{array}$ & 0.744 \\
\hline 4. Teacher attitude. & $\begin{array}{c}2.486 \\
.960\end{array}$ & $\begin{array}{c}1.285 \\
.487\end{array}$ & $\begin{array}{c}1.882 \\
.927\end{array}$ & $7.101^{*}$ & $\begin{array}{c}2.074 \\
.883\end{array}$ & $\begin{array}{l}1.950 \\
1.099\end{array}$ & $\begin{array}{l}2.142 \\
1.027\end{array}$ & 1.329 \\
\hline $\begin{array}{l}\text { 5. Lack of school day } \\
\text { time for learning and } \\
\text { using technology. }\end{array}$ & $\begin{array}{l}1.972 \\
1.092\end{array}$ & $\begin{array}{r}1.428 \\
.534\end{array}$ & $\begin{array}{c}2.352 \\
.785\end{array}$ & 2.126 & $\begin{array}{l}2.074 \\
1.035\end{array}$ & $\begin{array}{c}2.100 \\
.967\end{array}$ & $\begin{array}{c}1.785 \\
.974\end{array}$ & 0.479 \\
\hline $\begin{array}{l}\text { 6. Lack of teachers' } \\
\text { ability to design } \\
\text { educational activities. }\end{array}$ & $\begin{array}{l}2.810 \\
1.287\end{array}$ & $\begin{array}{c}1.428 \\
.786\end{array}$ & $\begin{array}{c}2.588 \\
.712\end{array}$ & $4.197^{*}$ & $\begin{array}{l}2.444 \\
1.120\end{array}$ & $\begin{array}{l}2.850 \\
1.089\end{array}$ & $\begin{array}{l}2.500 \\
1.400\end{array}$ & 0.783 \\
\hline $\begin{array}{l}\text { 7. Inadequate } \\
\text { computer skills. }\end{array}$ & $\begin{array}{l}2.324 \\
1.395\end{array}$ & $\begin{array}{l}1.714 \\
1.112\end{array}$ & $\begin{array}{c}2.294 \\
.985\end{array}$ & 0.777 & $\begin{array}{l}2.333 \\
1.386\end{array}$ & $\begin{array}{l}1.950 \\
1.145\end{array}$ & $\begin{array}{l}2.500 \\
1.160\end{array}$ & 0.890 \\
\hline $\begin{array}{l}\text { 8. Lack of skill on how } \\
\text { to incorporate } \\
\text { technology into the } \\
\text { classroom curriculum. }\end{array}$ & $\begin{array}{c}1.974 \\
.957\end{array}$ & $\begin{array}{c}1.571 \\
.786\end{array}$ & $\begin{array}{c}1.941 \\
.826\end{array}$ & 0.590 & $\begin{array}{c}1.925 \\
.729\end{array}$ & $\begin{array}{l}1.850 \\
1.136\end{array}$ & $\begin{array}{c}2.000 \\
.877\end{array}$ & 0.109 \\
\hline $\begin{array}{l}\text { 9. Failure to develop a } \\
\text { long term plan. }\end{array}$ & $\begin{array}{l}2.810 \\
1.174\end{array}$ & $\begin{array}{l}1.571 \\
.534\end{array}$ & $\begin{array}{c}2.764 \\
.752\end{array}$ & $4.362 *$ & $\begin{array}{c}2.592 \\
.971\end{array}$ & $\begin{array}{c}2.600 \\
.882\end{array}$ & $\begin{array}{l}2.857 \\
1.511\end{array}$ & 0.335 \\
\hline $\begin{array}{l}\text { 10. Inadequate training } \\
\text { of administrators, } \\
\text { teachers, and students. }\end{array}$ & $\begin{array}{l}2.108 \\
1.242\end{array}$ & $\begin{array}{c}1.714 \\
.755\end{array}$ & $\begin{array}{c}2.058 \\
.899\end{array}$ & 0.361 & $\begin{array}{l}2.000 \\
1.037\end{array}$ & $\begin{array}{l}2.050 \\
1.276\end{array}$ & $\begin{array}{l}2.142 \\
1.027\end{array}$ & 0.071 \\
\hline 11. Lack of a plan. & $\begin{array}{l}2.729 \\
1.261\end{array}$ & $\begin{array}{r}1.428 \\
.534\end{array}$ & $\begin{array}{c}2.588 \\
.795\end{array}$ & $4.031^{*}$ & $\begin{array}{c}2.592 \\
.971\end{array}$ & $\begin{array}{c}2.400 \\
.994\end{array}$ & $\begin{array}{l}2.642 \\
1.645\end{array}$ & 0.240 \\
\hline $\begin{array}{l}\text { 12. Selection of } \\
\text { hardware and software. }\end{array}$ & $\begin{array}{c}2.621 \\
.981\end{array}$ & $\begin{array}{r}1.857 \\
.690\end{array}$ & $\begin{array}{c}2.000 \\
.866\end{array}$ & $3.959^{*}$ & $\begin{array}{c}2.407 \\
.971\end{array}$ & $\begin{array}{c}2.150 \\
.933\end{array}$ & $\begin{array}{l}2.571 \\
1.016\end{array}$ & 0.892 \\
\hline $\begin{array}{l}\text { 13. Lack of } \\
\text { considering human } \\
\text { resistance to change. }\end{array}$ & $\begin{array}{l}2.702 \\
1.023\end{array}$ & $\begin{array}{c}1.428 \\
.534\end{array}$ & $\begin{array}{l}2.235 \\
1.147\end{array}$ & $4.586^{*}$ & $\begin{array}{l}2.333 \\
1.174\end{array}$ & $\begin{array}{c}2.750 \\
.966\end{array}$ & $\begin{array}{c}2.142 \\
.864\end{array}$ & 1.629 \\
\hline $\begin{array}{l}\text { 14. Lack access to } \\
\text { computers }\end{array}$ & $\begin{array}{l}1.918 \\
1.064\end{array}$ & $\begin{array}{r}1.857 \\
.899\end{array}$ & $\begin{array}{c}1.647 \\
.785\end{array}$ & 0.497 & $\begin{array}{l}1.888 \\
.933\end{array}$ & $\begin{array}{l}1.650 \\
.875\end{array}$ & $\begin{array}{l}2.000 \\
1.176\end{array}$ & 0.589 \\
\hline $\begin{array}{l}\text { 15. Lack of teacher } \\
\text { involvement in the } \\
\text { construction of plan. }\end{array}$ & $\begin{array}{l}2.216 \\
1.315\end{array}$ & $\begin{array}{l}2.000 \\
1.000\end{array}$ & $\begin{array}{c}2.588 \\
.712\end{array}$ & 0.779 & $\begin{array}{l}2.444 \\
1.219\end{array}$ & $\begin{array}{c}2.050 \\
.887\end{array}$ & $\begin{array}{l}2.357 \\
1.336\end{array}$ & 0.663 \\
\hline $\begin{array}{l}\text { 16. Lack of a financial } \\
\text { plan. }\end{array}$ & $\begin{array}{l}2.486 \\
1.193\end{array}$ & $\begin{array}{r}1.428 \\
.786\end{array}$ & $\begin{array}{c}2.411 \\
.795\end{array}$ & 2.762 & $\begin{array}{c}2.481 \\
.935\end{array}$ & $\begin{array}{l}2.300 \\
1.218\end{array}$ & $\begin{array}{l}2.142 \\
1.231\end{array}$ & 0.469 \\
\hline $\begin{array}{l}\text { 17. Lack of time for } \\
\text { teachers to learn how } \\
\text { to use computer } \\
\text { technology. }\end{array}$ & $\begin{array}{l}1.918 \\
1.010\end{array}$ & $\begin{array}{l}1.714 \\
1.112\end{array}$ & $\begin{array}{c}2.352 \\
.996\end{array}$ & 1.489 & $\begin{array}{l}2.074 \\
1.106\end{array}$ & $\begin{array}{c}1.950 \\
.944\end{array}$ & $\begin{array}{l}2.000 \\
1.037\end{array}$ & 0.094 \\
\hline $\begin{array}{l}\text { 18. Lack of motivation } \\
\text { for teachers. }\end{array}$ & $\begin{array}{l}3.027 \\
1.343\end{array}$ & $\begin{array}{r}1.857 \\
.690\end{array}$ & $\begin{array}{c}2.000 \\
.894\end{array}$ & $6.318^{* *}$ & $\begin{array}{l}2.925 \\
1.174\end{array}$ & $\begin{array}{l}2.368 \\
1.498\end{array}$ & $\begin{array}{l}2.357 \\
1.081\end{array}$ & 1.722 \\
\hline $\begin{array}{l}\text { 19. Lack of teacher } \\
\text { involvement in } \\
\text { selecting hardware and } \\
\text { software. }\end{array}$ & $\begin{array}{l}2.594 \\
1.021\end{array}$ & $\begin{array}{r}2.142 \\
.690\end{array}$ & $\begin{array}{l}2.375 \\
1.024\end{array}$ & 0.943 & $\begin{array}{l}2.814 \\
1.039\end{array}$ & $\begin{array}{c}2.050 \\
.998\end{array}$ & $\begin{array}{c}2.461 \\
.518\end{array}$ & $3.646^{*}$ \\
\hline $\begin{array}{l}\text { 20. Lack of an } \\
\text { instructional model for } \\
\text { teachers. }\end{array}$ & $\begin{array}{c}2.459 \\
.802\end{array}$ & $\begin{array}{c}1.571 \\
.534\end{array}$ & $\begin{array}{l}2.117 \\
1.053\end{array}$ & $3.521 *$ & $\begin{array}{c}2.444 \\
.800\end{array}$ & $\begin{array}{c}2.300 \\
.978\end{array}$ & $\begin{array}{c}1.857 \\
.864\end{array}$ & 2.343 \\
\hline $\begin{array}{l}\text { 21. Lack of skills in } \\
\text { the use of computers. }\end{array}$ & $\begin{array}{l}2.351 \\
1.252\end{array}$ & $\begin{array}{l}1.857 \\
1.069\end{array}$ & $\begin{array}{c}2.117 \\
.992\end{array}$ & 0.631 & $\begin{array}{l}2.148 \\
1.231\end{array}$ & $\begin{array}{l}2.250 \\
1.208\end{array}$ & $\begin{array}{l}2.357 \\
1.008\end{array}$ & 0.147 \\
\hline
\end{tabular}


Nine of the inhibitor items $3,4,6,9,11,12,13,18$, and 20 yielded a significant main effect of position. Inhibitor item 19 yielded a significant main effect by district. The results of the Fisher's Least Significant Difference test indicated that Myersdale school district had significantly lower scores than Turkeyfoot school district, while there was no significant difference between Rockwood school district and Turkeyfoot school districts' or Rockwood school district and Myersdale school district. 


\section{CHAPTER V}

\section{FINDINGS, CONCLUSIONS, AND RECOMMENDATIONS}

Introduction

This chapter contains three sections. Section One summarizes the research. Section Two states the findings and conclusions derived from the analysis of data. Section Three includes the implications and recommendations for further research.

\section{Summary}

The purpose of this research study was to provide school board members, school administrators, and teachers with information required in developing a successful plan for the integration of computer technology into the classroom curriculum. The stated problem of this research was to identify and analyze the factors that inhibit and enhance the implementation of computer technology into the classrooms of a small rural school district.

A review of the literature was conducted in the following areas: (a) the use of computer technology in K-12 rural school districts; (b) enhancers to the integration of computer technology into the classroom curriculum in small rural school districts; (c) inhibitors to the integration of computer technology into the classroom curriculum in small rural school districts; (d) research designs in studying technology utilization. The literature review identified three positions as important elements of computer integration: teachers, administrators, and school board members. These three positions participated in the study. The survey return rate for participants was $51 \%$ or 61 participants. The instrument used in this study was designed as a six point Likert scale. Two Likert scale 
instruments were used, one for the 21-inhibitor items and the second for the 19enhancer items. The data from the two Likert scales were analyzed using a twoway ANOVA. The raw scores were used in the statistical analysis and a significance level of $p \geq .05$ was selected. When required, the post-hoc analysis of significance F-tests was performed using the Fischer's Least Significant Difference Test. The statistical program used in this study was the S-Plus program.

There was a high rate of agreement between the literature review and the positions of teachers, school administrators, and school board members of what enhanced and inhibited integration of computers into the classroom curriculum of a small rural school district. Administrators believe that teachers are one of the most significant reasons that the integration of computers into the classroom has been slow. This research has indicated that the literature review and the results of this research concur; however, the literature review did not give any indication regarding the relationships among the positions and how these relationships' impact the success of computer integration into the classroom curriculum.

\section{Statement of the Problem}

The problem of this research was to identify and analyze the factors that act as inhibitors and enhancers to implementing computer technology into the classroom curriculum of a small rural school district. 


\section{Findings: Related to Research Questions 1 and 2}

Research questions 1 and 2 were answered simultaneously using a twoway ANOVA. Question 1 stated: Were there differences among the positions of teachers, school administrators, and school board members regarding enhancers and inhibitors to the process of integrating computers into the classroom curriculum? Question 2 stated: Were there differences between school districts regarding their opinion of enhancers and inhibitors to the process of integrating computers into the classroom curriculum?

\section{Findings: Enhancers}

The first research question was "Were there differences among the positions of teachers, school administrators, and school board members regarding enhancers and inhibitors to the process of integrating computers into the classroom curriculum? The results of the 19-enhancer item ratings indicated that there was a significant main effect of position on enhancer item 10, and an interaction of position as a function of district on enhancer item 18.

Enhancer item 10 was "Decentralized decision-making regarding actual use of the innovation." The two-way ANOVA indicated a main effect of position. There was no evidence to indicate that there was any difference between school board members and teachers. This finding was not consistent with the literature regarding how teachers and students feel about the use of computers and the adoption of computer technology into the classroom curriculum and the perceived need for strong leadership (Barker and Hall, 1998; Caffolla and Knee, 1998; Becker, 1994). They suggested that decentralization decision-making 
would permit the user the opportunity to implement ideas without the impediment of supervision. However, teachers seem to feel a need for supervision or leadership in the process of integrating computers into the classroom curriculum.

The second enhancer survey item that indicated a significant difference was enhancer item 18. This enhancer item was "Innovativeness or willing to change". Therefore, administrators at Turkeyfoot School District indicated that innovativeness or willingness to change was not an enhancer to the integration of computers into the classroom curriculum in a rural school district.

The implication of the statement by Turkeyfoot administrators was in conflict with the literature review. Marcinkiewicz (1993), Martin (1988), Dupagne and Krendl (1991), Baack, Brown, and Brown (1992), and Hunt and Bohlin (1993) agreed that innovativeness or willingness to change would open the process for integrating computers into the classroom. This would also indicated that administrators with the same opinion were likely to experience difficulty working or motivating their teaching staff in the process of integrating computers into the classroom curriculum.

\section{Findings: Inhibitors}

It was found that the inhibitor survey results indicated that ten inhibitor items had a significant difference. The inhibitor statistical conclusions presented nearly the same profile as the enhancer results. Administrators agreed and teachers disagreed with nine of the ten-inhibitor items. Brichner (1995) identified the lack of an instructional model for teachers to maximize the use of computer technology as a major inhibitor to the computer integration process. The school 
board members appeared to understand the administrator position and at the same time agreed with the teacher position for the nine-inhibitor items discussed in this section. The tenth inhibitor item, 19, indicated that there was a significant main effect of district. Inhibitor item 19 indicated that administrators had significantly lower scores than did the teachers and school board members. A possible reason for this result is that school board members are in the unique position to be able to hear both sides of the statement or item. There were no statistical differences between Turkeyfoot and Rockwood School Districts, and there were no statistical differences between Myersdale and Rockwood School Districts. It can be concluded, based on the results for this item, that the Turkeyfoot School District does not subscribe to the observations and research of the authors in the literature review, who have demonstrated that the lack of teacher involvement in the selection of hardware and software often results in a failed attempt at the computer integration process (Baack, Brown and Brown, 1991; Dupagne and Krendl, 1992; Hunt and Bohlin, 1993). These authors stated that teacher involvement in the process of selection of both hardware and software were the primary ingredient for successful computer integration into the classroom curriculum. This study of integrating computers into the classroom of a small rural school district was viewed as a study of change. Change requires that all aspects of the current practice be reviewed and all stakeholders included in the process. Past practice did not allow rural, city, or urban school districts' to integrate computers into the classroom curriculum. 
However, the overall indication within this study was that the real challenge to integrating computers into the classroom curriculum of a small rural school district was that a more diverse constituency of people, schools, and communities had the ability to empower and lend long term support to education reform (Kimpton and Sharp, 1997). This type of action would enhance communication and build trust between the positions and the community in the small rural school district.

\section{$\underline{\text { SUMMARY }}$}

A summary of the enhancer results of the 19-enhancer item ratings indicated that there was a significant main effect of position on enhancer item 10 and an interaction of position as a function of district on enhancer item 18. Item (E10) was "Decentralized decision-making regarding actual use of the innovation." The second enhancer survey item that indicated a significant difference was enhancer item 18. This enhancer item was "Innovativeness or willing to change." Both of these enhancer items indicated a disagreement between the teacher and administrator positions. Reviewing the results indicates that teachers and administrators differed significantly on nine of the ten inhibitors. Therefore, based on the information described above, the challenge at hand for small rural school districts appears to be a basic one of communication among the positions.

Inhibitor item 19 was "Lack of teacher involvement in selecting hardware and software" found a difference between school districts. The results suggest that some districts have included involvement of the teachers in the process of the selection of hardware and software. The review of the literature supported 
the active participation of teachers in this part of the process of integrating computers into the classroom.

Conclusions of the research

As a result of the research questions posed, this researcher made the following conclusions:

1) There was a high rate of consistency regarding agreement among the literature review and the three positions -- teachers, school administrators, and school board members -- of what were enhancers and inhibitors to integrating computers into the classroom curriculum of a small rural school district.

2) Teacher training for the purpose of skill building continued to be an area overlooked regarding its impact on teachers accepting their role as the innovation coordinator in the small rural school district.

3) School board members more closely agreed with teachers rather than administrators when rating the challenges of integrating computers into the classroom of the small rural school district. School board members have the unique opportunity to be in a position to hear both teacher and administrator opinions. Often there was less resistance between teachers and school board members than between school board members and administrators.

4) The dynamics of the relationship between the positions appear to be stressed continually. Teachers wanted direction, while administrators 
wanted to give the teachers freedom to work at their own pace, immediately compromising clear communication between these positions. If positive communication does not occur between administrators and teachers, the fallout can result in failure to meet the challenges that are presented to administrators. Another stress factor may be when administrators make a decision regarding hardware or software without conferring with the teachers.

5) The analysis of data indicated that the teachers, administrators, and school board members recognized the inhibitors and enhancers to their roles in integrating computers into the classroom curriculum. The roles appeared to be that teachers were the implementers of the innovation, administrators were the planners and supervisors, and the school board members acted to draw all three positions together.

6) The literature review and the results of this research did not suggest how the relationships among positions impacted the success of computer integration into the classroom curriculum.

7) This research data supported the theory that small rural school districts shared similar challenges in integrating computers into the classroom.

\section{Implications of the Research}

The purpose of this research study was to provide school board members, school administrators, and teachers with information that was required in developing a successful plan for integrating computer technology into the classroom curriculum in a small rural school district. Statistical data presented in 
this research supported the idea that developing and implementing a successful plan for integrating computers into the classroom curriculum of a small rural school required support among the three positions identified in the research. Further implications predict that this difficult process of computer integration into the classroom curriculum will continue to be erratic in development unless strong leadership is present. This strong leadership requires administrators to modify their approaches to the planning process. Administrators must include the appropriate stakeholders that are needed in the planning process.

Training in skill development for teachers in developing an understanding of computer use, internet use, hardware and software selection, software modification, spreadsheet and database is essential. Also included in this plan must be a financial plan, and an appropriate instructional model for teachers. It is important to identify a successful integration model where teachers have already integrated software and hardware into courses to accomplish specific objectives. Teachers require a positive experience in the integration process. The overall plan should also include time for teachers to learn and apply the skills needed to include computers into the classroom curriculum. This research data indicated that the 19-enhancer items were perceived by teachers, administrators, and school board members as important elements in a successful plan for integrating computers into the classroom of a small rural school district. Once this is presented and accepted by the stakeholders, the process is safe to begin. This agreement between positions or stakeholders is only the beginning and only indicates that even when all agree, the process of integrating computers into the classroom continues to be a difficult process. This difficulty may have its challenge in the area of human resistance to change. 
This research is about change and the nature of change in rural school districts in the case of integrating computers into the classroom. Dupagne and Krendl (1992) suggested that the level of enthusiasm about computer use increases with individual computer experience. Direct experience and selfknowledge go hand in hand. Rural schools and rural communities, find difficulty accepting new innovations. This is directly related to a number of varibles within the rural community. Past practices, religious beliefs, and general beliefs are part of the barriers of acceptance of any new innovation. While these attitudes are present in city and urban school district communities, these attitudes are more pronounced in the rural community. Kimpton and Sharp (1997) found that the community serves as a primary power element in supporting a school district's objectives of education reform. The overall findings of the current theory and this research were proven to be what the data defined as current practice.

\section{Recommendations for Further Research}

The following recommendations were made as a result of this research.

1) The most obvious recommendation for additional research on the topic of integrating computers into the classroom curriculum would be to replicate this study and include additional rural school districts. In addition to this study of rural schools, a study of suburban and city school districts should be conducted to investigate the differences among the three, and how the 
characteristics of each impact the integration of computers into the classroom curriculum of each type of school district.

2) Additional research should be conducted to determine to what extent a lack of communication contributes to the failure of school districts to meet educational goals.

3) The opportunities that act as enhancers and the barriers that act as inhibitors to the integration of computers into the classroom curriculum, especially as they relate to the student and community, must be further explored.

4) This study should be repeated in the same school districts at a later date to determine the success of the computer integration process.

5) A study should be conducted to observe successes regarding the methods and procedures that teachers are currently using to integrate computer technology into their classroom curriculum.

It is important to have a full understanding of the process of integrating computers into the classroom curriculum before a school district develops a longterm plan. It is important to understand how comprehensive the process is and to involve community members, teachers, administrators, students, and school board members. 


\section{Bibliography}

American Association for the Advancement of Science, (1989), 39 (AAAS)

Washington, DC.: AAAS.

American School Board Journal, (1997) Electronic school, American School Board Journal 184 (1), 32.January

Austin, T. (1993). The technology advisory council: $\underline{A}$ vehicle for improving our schools. Eugene, Oregon: International Society for Technology in Education.

Baack, S., Brown, T., \& Brown, J. (1991). Attitudes towards computers: Views of older adults compared with those of young adults. Journal of Research on Computing in Education. 23 (3), 422 - 433.

Barker, B. \& Hall, R. (Spring,1998). Planning for technology implementation in rural schools. Rural Educator 19 (3), p.1-6

Barker, B. (1990). Planning, using the new technology in classrooms. NAASP Bulletin, 74 (529), 31-37.

Baugh, J. (1994). Internet use in the Rural School, Dissertation Abstracts International, 59-12-B, 9032.

Beaulieu, L., \& Mulkey, D. (1995). Investing in people: The human capital needs of rural America. Boulder, CO.: Westview.

Becker, J. (1994a). Conclusion to analysis and trends of school use of new information technologies. Washington, DC.: Office of Technology Assessment U.S. Congress.

Becker, J. (1994b). How Exemplary Computer-Using teachers differ from other teachers. Implications for realizing the potential of computers in schools. Journal of Research on Computing in Education. 26 (3), 291-319.

Bell, J.D. (1991) New technology and new potential, State Legislative Report: 16 (6), July, 1991 (10) Denver, CO.

Bolton, W. (1994). Factors that may influence the use of computer technology in the teaching and learning process. Dissertation Abstracts International, 57,02a. 3476 133

Borg, W., \& Gall, M. (1989). Educational research: An introduction. New York: Longman.

Bork, A. (1984), Computers future for education, Creative Computing, 178, 180. 
Brickner, D. (1995). The effects of first and second order barriers to change on the degree and nature of computer usage of mathematics teachers: A case study. Doctoral Dissertation Purdue University, 1995. Dissertation Abstracts International, 56-07a, 2647322.

Brody, P. (1995). Technology planning and management handbook. New Jersey: Educational Technology Publications.

Brouillette, L. (1996). A Geology of School Reform. State University of New York Press: Albany, NY.

Burnell, G. (February,1994). Technology as a tool for urban classrooms. ERIC Clearinghouse Digest on Urban Education 1994. February.

Bushweller, K. (1996). How do US. schools stack up? Educational Vital Signs 1996 December. A9 - A31.

Caffolla, R. \& Knee, R. (1998). Factors limiting technology integration in education Available http: //www.coe.uh.edu/insite/elec

Campoy, R. (1992). The role of technology in the school reform movement. Educational Technology. (Aug.). 17-22.

Cannings, T \& Finkel, L. (1993). The technology age classroom. Wilsonville, Oregon : Franklin, Beedle \& Associates Inc.

Capper, C. (1993). Rural community influences on effective school practices. Journal of Educational Administration, $\underline{31(3) .20-38 . ~}$

Carey, D. (1993). Teacher roles and technology integration: moving from teacher as director to teacher as facilitator. Computers in the schools 9, 105. The Haworth Press, Inc.

Carter, G. (1994). Can Information Technology really change American Education? Association for Supervision and Curriculum Development Update, 36 (7), 2

Chickering, A. \& Ehrmann, S. (1997). Implementing the Seven Principles: Technology as Lever. American Association for Higher Education. [Online]. Available: http://www.aahe.org/technology/ehrmann.htm.

College of Education AT \& T University Equipment Project. (1997). Integrated Media Education Lab. Available: http://semonkey.ed.asu.edu/

Cone, J. \& Foster, S. (1993). Dissertations and thesis from start to finish. Washington, DC. :American Psychological Association. 
Cox, M., Rhodes, V., \& Hall, J. (1988). The use of computer-assisted learning in primary schools: Some factors affecting the uptake. Computer Education, 12 (1), 173-178.

Cradler, J. (1995). Summary of Current Research and Evaluation Findings on Technology Reform. [Online]. Available: htt://www.fwl.org/techpolicy/refind.html.

Cradler, J. (1993). California Implements a Plan to Improve Education with the Assistance of Technology. Educational Media and Technology Yearbook. Englewood, CO: Libraries Unlimited.

Cuban, L. (1993). Computers meet classroom: Classroom wins. Teachers College Record. 95, 185-210.

Davenport, M. (1995). Factors related to the Tennessee K-12 educators' implementation of the internet into classroom activities and professional development.

Dissertation Abstracts International, 54-12A, 3225.

David, J. (1991). Restructuring and Technology: Partners in Change. Phi Delta Kappan. $\underline{73}$ (1), 37-81.

Davidson, O. (1991). Broken Heartland: The rise of America's rural ghetto. New York: Anchor Books.

Davidson, D., \& Ritchie, S. (1994). How do attitude of parents, teachers, and students affect the integration of technology into schools ? Paper presented at the 1994 National Convention of the Accociation for Educational Communication and Technology.

DeYoung, A. (1995). The life and death of a rural American high school. New York: Garland

DeYoung, A. (1991). Rural education: issues and practice. New York: Garland Publishing.

Dupagne, M. \& Krendl, K. (1992). Teacher's attitudes towards computers: A review of literature. Journal of Research on Computing in Education. 24 (3), 420-427.

Edumunds, R. (1985). The Prentice-Hall standard glossary of computer terminology. Englewood Cliffs: Prentice-Hall, Inc.

Egan, K. (1978). What is curriculum? Curriculum Inquiry, $\underline{8}$ (1).

Elder, W. (1991). A descriptive analysis of rural schools and rural districts. Columbia, MO.: University of Missouri, Office of Social and Economic Data Analysis. 
Ellis, A. \& Fouts, J. (1993). Research on educational innovations. Princeton Junction, NJ.: Eye on Education.

Emery, F. \& Oeser, O. (1958). Information, decision and action: A study of psychological determinants of change in farming techniques. New York: Cambridge University Press.

Gainey, D. (1994). The American high school and change: an unsettling process. NASSP Bulletin. (March) 26-34.

Gagne, R. \& Merrill, M.D. (1990). Integrative goals for instructional design. Educational Technology Research and Development 38: 23-30.

Galbraith, M. (1992). Education in the rural American community. Malabar, Fla.: Krieger Publishing Company.

Geisert, P. \& Futrell, M. (1995). Teachers computers, and curriculum. Boston : Allyn and Bacon.

Global School Net Foundation. (1996). Changing Roles and Increasing Participation. [Online]. Available: http://www.gsn.org/web/reform/roles.htm.

Grandgenett, N., Grandgentt, D., Topp, N., Fluckiger, J., Oslter, E., and Mortenson, R. (1997). Integrating technology into teaching and learning: The three keys to the kingdom. Journal of SEDA 34 (4), (Nov. 97) 252,255.

Gulliford, A. (1996). America's country schools. Niwot, Colorado : University Press of Colorado.

Hall, G. ,George, T. and Rutherford, W. (1986). Measuring Stages of Concern About the Innovation, A Manual for Use of the SoC Questionnaire. CBAM manual, Project of the Research and Development Center for Teacher Education, The University of Texas at Austin.

Hall, G. , Loucks, S., Rutherford, W., and Newlove, B. (1975). Levels of Use of the Innovation: A Framework for Analyzing Innovation Adoption. Journal on Teacher Education, 26, (1)

Hammond, N., Gardner, N., Heath, S., Kibby, M., Mayes, T., McAlesse, R., Mullings, C., and Trapp, A. (1992). Blocks to Effective use of information technology in Higher Education. Computer Education, 18 (1), 155-162.

Hannafin, M., Hannafin, K., Hooper, S., Rieber, L., \& Kini, A. (1996). Research on and research with emerging technologies. Handbook of research on educational Communication and Technology, 378-402. New York: Scholastic. 
Harvey, G. (1990). Implementing technology in the classroom: Paths to success and failure. Eric Document Reproduction Service N. ED. 326197.

Hass, T. (1992). Leavinghome: Circumstances afflicting rural America during the last decade and their impact on public education Peabody Journal of Education, $\underline{67}$ (4), 7-28.

Heaviside, S. (1995). Advanced telecommunications in US. public schools. ERIC Document Reproduction Service N. ED. 378959.

Henry, M., Drabenstoff, M., \& Gibson, L. (1986). A changing rural America. Economic Review (July).

Hertzke, E. \& Olson, W. (1994).T.Q.E., technology and teaching. Thousand Oaks, California : Corwan Press, Inc.

Hinrichs, C. (1999). S-Plus Student Edition. MathSoft, Inc.Cambridge, MA.: Brooks/Cole Publishing Company.

Hobbs, D. (1991). Rural education. In C. B. Flora \& J. A. Christenson (Eds.), Rural policies for the 1990s, 151-165. Boulder, CO.: Westview Press.

Hooper, S. and Hannafin, M.J. (1991). Psychological perspectives on emerging instructional technologies: A critical analysis. Educational Psychologist 26: 69-95.

Howley, C.B. (1994). The academic effectiveness of small-scale schooling: An update ERIC Digest NO. (Edo-RC-94-1). Charleston, WV.: ERIC Clearing House on Rural Education and Small Schools.

Hunt, N. and Bohlin, R. (1993). Teacher education students' attitudes towards using computers. Journal of Research on Computing in Education, 25 (4), 486-497.

Hunter, B. and Richards, J. (1996). Learner Contributions to Knowledge, Community, and Learning. [Online]. Available:http://www.ed.gov/Technology/Futures/hunter.html.

Jacobs, J. (1988). The social implications of computers: Ethical and Equity Issues. Outlook, 20:1, 100-114.

Jonassen, D. (1996). Computers in the classroom: Mindtools for critical thinking. Englewood Cliffs, NJ.: Merrill.

Jones, T., \& Clarke, V. (1994). A computer scale for secondary students. Computers \& Education, 22, 315-318.

Jorde, P. (1986). Microcomputers: Tempering the pro-innovation bias. Education, 1 , 106 (4) 388-393. 
Kay, A. (1996). Revealing the elephant: The use and misuse of computers in education. Educom Review. 31, 22-31.

Kearsley, G., Hunter, B., \& Furlong, M. (1992). We teach with technology. Wilsonville, OR.: Franklin, Beedle \& Associates.

Kearsley, G. \& Lynch, W. (1992). Educational leadership in the age of technology: The new skills. Journal of Research on Computing in Education. 25 (1) 50-60.

Kimpton,J., \& Sharp, M. (1997). A report of the Annenberg Institute on public engagement for public education. Providence, RI.: Brown University.

Kinnaman, D. (1990). The next decade: What the future holds. Technology and Learning. (Sept.). 42-49.

Knapp, L \& Glenn, A. (1996). Restructuring schools with technology. Boston : Allyn and Bacon.

Kozol, J. (1991). Savage Inequalities: Children in America's schools. New York: Crown Publisher.

Kromhout, O., \&Butzin, S. (1993). Integrating computers in the elementary school curriculum: An evaluation of nine Project CHILD model schools. Journal of Research on Computing in Education, 26 (1), 55-69.

Lane, C. (1995). Strategic planning: Providing interaction through mixed media in University distance learning programs. On line. Available on the WWW @ :http://www.fwl.org/edtech/strategic.html.

LaQuery, T. (1994). The internet companion plus. Reading, MA.: Addison-Wesley.

Loucks, S., Newlove, B., and Hall, G. (1976). Measuring Stages of Concern About the Innovation, A manual for use of the SoC Questionnaire. CBAM manual, Project of the Research and Development Center for Teacher Education, The University of Texas at Austin.

Marcinkiewicz, H. (1991). Levels of use of the innovation: A framework for analyzing innovation adoption. The Journal of Teacher Education. 26 (1), 52-56.

Marcinkiewicz, H. (1993). Computer and teachers: Factors influencing computer use in the classroom. Journal of Research on Computing in Education. 26, 220-237.

Martin, D. (1988). School district implementation of microcomputers for instruction. Journal of Research on Computing in Education, Winter (6), 212-227. 
Mauch, J. \& Birch, J. (1993). Guide to the successful thesis and dissertation. New York: Marcel Dekker, Inc.

McDaniel, E., Mclnerney, W., \& Armstrong, P. (1993). Computers and school reform. Education Training Research \& Development 41, 73-78.

McKenze, J. (1993). Selecting, managing, and marketing technologies. Newbury Park, California : Corwin Press, Inc.

Means, B. (1994) . Technology and education reform. San Francisco, California : Jossey-Bass Publications.

Means, B. (1993). Using technology to support education reform. Washington, DC. : U.S. Government Printing Office.

Mehlinger, H. (1995). School reform in the information age. Bloomington, IN.: Center For Excellence in Education. Indiana University.

Miller, B. (1993). Rural distress and survival: The School and the Importance of "Community." Journal of Research in Rural Education, $\underline{9}$ (2), 84-103.

Minzey, J., \& LeTarte, C. (1972). Community education: From program to process. Midland, Ml.: Pendell.

Molseed, T.(1997). Evaluating restructuring indicators for rural schools. $\underline{\text { Rural }}$ Educator 19 (1).

National Center for Education Statistics (1998). Internet Access in Public Schools. [Online]. Available:http://nces.ed.gov/pubs98/98031.html.

National Center for Education Statistics (1995). Common core of data. Washington, DC.

National Commission of Excellence in Education (1983), A Nation at Risk: The imperative for educational reform government printing press, Washington, DC.

Novak, J. (1997). A Theory of Education. Ithaca, N.Y.: Cornell University Press.

Nua Internet Surveys (1998). Intelliquest: 62 million people online in the US. Dublin, Ireland: Nua Ltd.

Owens, E.W. (1993) Technology access and use in urban, suburban, and rural eighth grade mathematics classrooms. Technology and teacher education annual, (528530). Charlottesville, VA, Association for the Advancement of Computing Education. 
Owens, E.W. and Wasman, H.C. (1994) Differences among urban and rural high schools on technology use in science and math. Technology and teacher education annual (589-592), Charlottesville, VA. Association for the Advancement of Computing in Education.

Owens, S. (1995). Implementing telecommunications in a rural school district: Promise and pursuit. Dissertation Abstract International, 55-04 3231

Perelman, L. (1992). Schools out. New York : William Morrow and Company, Inc.

Picciano, A. (1994). Computers in the schools. New York: Merrill.

Pitrowski, S. (1992). Computer training; Pathway from extinction. (Report No. 1Ro15617) ERIC Document.

Poindexter, B. (1997). Meeting the needs of your Rural Community and Students. Program description. Conference Paper.

Reigeluth, C., \& Garfinkle, R. (1992). Envisioning a new system of education. Educational Technology. (NOV.). 17-27.

Rapp, C. (1997). A survey of factors affecting computer implementation in rural Northeast Tennessee K-12 public schools. Doctoral Dissertation. East Tennessee

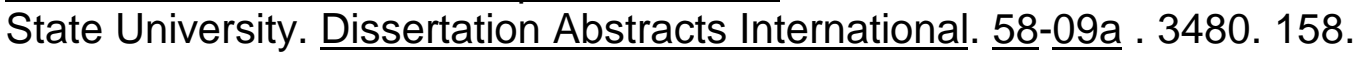

Rieber, L., \& Welliver, P. (1989). Infusing educational technology into mainstream educational computing. International Journal of Instructional Media. 16 (1), 21-31.

Riedl, J. (1995). The integrated technology classroom. Boston :Allyn and Bacon.

Rivera, E., Smaby, M., \& Maddux, C. (1996). Chaos theory and computers. Computers in the Schools. 12 (4), New York : Haworth Press.

Robinson, B. (1995). Learning to use information technology in schools: What lessons are we learning? Journal of Information Technology for Teacher Education. 4, 3-6.

Rogan,J. (1997). Online mentoring: Reflections and suggestions. Journal of Computing in Teacher Education: 13 (3), 5-13. April 1997.

Rogan,J. (1996). Rural teachers meet the internet. Journal of Computing in Teacher Education: 12 (3), 21-25.

Rogers, E. (1995). Diffusion of innovations. New York: Free Press.

Rose, A. (1992) Financing technology. American School Board Journal, July , 162 (1), 17. 
Sasala, M. (1994). A descriptive study of the implementation of secondary curriculua offerings in Pennsylvania small school districts: small rural schools and small non rural school districts. Doctoral Dissertation, University of Pittsburgh. Dissertation Abstracts International. 57-07a. 2841, 147.

Scheidler, K. (1994). Changing teacher thinking in school restructuring: A view from the trenches. Journal of Education. 176. 45-54.

Seidel, R., \& Perez, R. (1994). Technology assessment in software application. Hillsdale, NJ.: Lawrence Erlbaum Associates.

Selwyn, N. (1997). Students attitude toward computers. Computers in Education $\underline{28}$ (1), 35, 41.

Sheingold, K. (1991). Restructuring for learning with technology: The potential for synergy. Phi Delta Kappan, (그), 17-27.

Sheingold, K. , Hadley, M. (1990). Accomplished teacher: Integrating computers into classroom practice. New York: Center for Technology in Education.

Shoemaker, T. (1997). Factors affecting the implementation of the internet use in Michigan K-12 schools. Doctoral Dissertation, Wayne State University. Dissertation $\underline{\text { Abstracts International. }}$ 58-03, 835, 00101.

Smith, T., \& Yellen, R. (1991). Factors inhibiting the introduction of computer assisted instruction. Collegiate Microcomputer. $\underline{9}$ (2), 117-122.

Software Publishers. (1992). Schools spend 2.7 billion on technology. Electronic Education 12 (4), 9-10.

Spot, T., \& Bowman, M. (1993). Increasing faculty use of instruction technology: Barriers and incentives. Educational Media International. 30:4, 199-204.

Spitzer, W. (1993). Environmental barriers to networking. Journal of Research in Rural Education, (Spring) $\underline{9}$ (1), 47-50.

Spring, J. (1990). The American school. New York: McGraw Hill.

Stephens, E. \& Bhaerman, R. (1992). Analyzing educational initiatives with rural eyesEducational Horizons, Winter, 92-96.

Stern, J. (1994). The condition of education in rural schools. Washington, DC.: U. S. Department of Education, Office of Educational Research and Improvement. 
Stern, D. , Stone, J., Hopkins, C., McMillion, M., \& Crain, R. (1994). School-based enterprise: Productive learning in American high schools. San Francisco, CA.: Jossey-Bass.

Stern, J. (1992). How demographic trends for the eighties affect rural and small-town schools. Educational Horizons, 71-77.

Stickel, S. (1992). Chaos Theory: Implications for non-linear dynamics in counseling. A paper presented at the annual meeting of Eastern Educational Research Association. Hilton Head, SC., March 3-7.

Stoddart, T, \& Neiderhauser, D. (1993). Technology and educational change. Computers in the Schools. 9 (2/3), 5-21.

Strommen, E., \& Lincoln, B. (1992). Constructivism, Technology and the Future of Classroom learning. Education and Urban Society. 24, 466-467.

Strudler, N. (1991), The role of school-based computer coordinators as change agents in elementary schools programs, case studies in computer aided learning, (222-271) London: Falmer Press.

Sun Associates, (1998). Educational Technology Integration. Available: http://www.Sun-Associates.com/eval.

Sutton, R. (1991). Equity and computers in the schools: A decade of research. Review of Educational Research. 61 (4), 475-503.

Terrell, S. (1995). A transition model for the introduction of technology. ERIC Document Reproduction Service No. ED. 386171.

The Center for Information Technology Integration (1998). Technology Integration. Available http://citi.umich.edu/

Theobald, P. (1991). Country lifers reconsidered: Educational reform for rural America. Journal of Research in Rural Education, 7(2), 22-28.

Thompson, A., Schmidt, D. \& Hadjiyianni, E. (1995). A three year program to infuse technology throughout a teacher education program. Journal of Technology and Teacher Education. $\underline{3}$ (i), 13-24.

Thompson, A. \& Simonson, N., Hargrave, C. (1993). A review of the research of technology education. Washington, DC : Association For Educational Communications and Technology.

United States Congress Office of Technology and Assessment (1995). Teachers and technology, making the connection. (OTA-EHR-616). Washington, DC.: United States Government Printing Office. 
Unks, G. (1989). Differences in curriculum within a school setting. Education and urban society, 21(2), 175-191.

U.S. DOE. (1996). Technology and Education Reform. [Online]. Available:http:www.ed.gov/pubs/EdReformStudies/Edtech/.

Wesley, M. \& Franks, M. (1994). The virtual classroom and vertically integrated technology training for education. Paper presented to the annual conference of Mid-State Educational Research Association, Nashville, TN.

Wiburg, K. (1994). Integrating technologies into school: Why has it been so slow? The Computing Teacher, 21, (5) 6-8.

Wiles, J., \& Bondi, J. (1993). The essential middle school . New York: Macmillian Publishing Company.

Willis, J. (1994). What conditions encourage technology use? It depends on the contex. $\underline{\text { Computers in the Schools. }} \underline{9}$ (4), 13-32.

Willis, J. \& Stephens, E. \& Matthew, K. (1993). Technology reading, and language labs. Boston : Allyn and Bacon.

Winnans, C., \& Brown, D. (1992). Some factors affecting elementary teachers' use of the computer. Computers Education. 18:4, 301-309.

Woodrow, J. (1991). A comparison of four computer attitude scales. Journal of Educational Computing Research. $\underline{7}, 165-187$.

Yocam, K. (1996). Teacher-centered staff development for integrating technology into the classroom. Technology Horizons in Education Journal. Nov. Available. http:/www.thejournal.com 
APPENDICES 


\section{APPENDIX A}

\section{Integrating Computers into the Classroom \\ ENHANCERS CODE}

Below are listed nineteen (19) enhancers to the integration of computers into the classroom.

(Please circle the trait that best indicates the degree of importance you perceive each of the enhancers.)

1) Broad-base support fueled by public support

$\begin{array}{cccccc}1 & 2 & 3 & 4 & 5 & 6 \\ \begin{array}{c}\text { STRONGLY } \\ \text { AGREE }\end{array} & \text { AGREE } & \begin{array}{c}\text { SLIGHTLY } \\ \text { AGREE }\end{array} & \begin{array}{l}\text { SLIGHTLY } \\ \text { DISAGREE }\end{array} & \text { DISAGREE } & \begin{array}{c}\text { DISAGREE } \\ \text { STRONGLY }\end{array}\end{array}$

2) Availability of information from early adopted school districts

$\begin{array}{cccccc}1 & 2 & 3 & 4 & 5 & 6 \\ \begin{array}{c}\text { STRONGLY } \\ \text { AGREE }\end{array} & \text { AGREE } & \begin{array}{c}\text { SLIGHTLY } \\ \text { AGREE }\end{array} & \begin{array}{l}\text { SLIGHTLY } \\ \text { DISAGREE }\end{array} & \text { DISAGREE } & \begin{array}{c}\text { DISAGREE } \\ \text { STRONGLY }\end{array}\end{array}$

3) Comprehensive, centralized planning of the entire process

$\begin{array}{cccccc}1 & 2 & 3 & 4 & 5 & 6 \\ \begin{array}{c}\text { STRONGLY } \\ \text { AGREE }\end{array} & \text { AGREE } & \begin{array}{c}\text { SLIGHTLY } \\ \text { AGREE }\end{array} & \begin{array}{c}\text { SLIGHTLY } \\ \text { DISAGREE }\end{array} & \text { DISAGREE } & \begin{array}{c}\text { DISAGREE } \\ \text { STRONGLY }\end{array}\end{array}$

4) Size of the school district with relatively few layers of bureaucracy

$\begin{array}{cccccc}1 & 2 & 3 & 4 & 5 & 6 \\ \begin{array}{c}\text { STRONGLY } \\ \text { AGREE }\end{array} & \text { AGREE } & \begin{array}{c}\text { SLIGHTLY } \\ \text { AGREE }\end{array} & \begin{array}{l}\text { SLIGHTLY } \\ \text { DISAGREE }\end{array} & \text { DISAGREE } & \begin{array}{c}\text { DISAGREE } \\ \text { STRONGLY }\end{array}\end{array}$

5) Provision of sufficient resources for hardware, software, staff development curriculum development and technical support.

$\begin{array}{cccccc}1 & 2 & 3 & 4 & 5 & 6 \\ \begin{array}{c}\text { STRONGLY } \\ \text { AGREE }\end{array} & \text { AGREE } & \begin{array}{c}\text { SLIGHTLY } \\ \text { AGREE }\end{array} & \begin{array}{l}\text { SLIGHTLY } \\ \text { DISAGREE }\end{array} & \text { DISAGREE } & \begin{array}{c}\text { DISAGREE } \\ \text { STRONGLY }\end{array}\end{array}$

6) Creation of the position of a district-wide computer coordinator.

$\begin{array}{cccccc}1 & 2 & 3 & 4 & 5 & 6 \\ \begin{array}{c}\text { STRONGLY } \\ \text { AGREE }\end{array} & \text { AGREE } & \begin{array}{c}\text { SLIGHTLY } \\ \text { AGREE }\end{array} & \begin{array}{l}\text { SLIGHTLY } \\ \text { DISAGREE }\end{array} & \text { DISAGREE } & \begin{array}{c}\text { DISAGREE } \\ \text { STRONGLY }\end{array}\end{array}$




\section{Integrating Computers into the Classroom}

\section{ENHANCERS}

CODE

7) Selection of uniform hardware and software that was compatible with the educational goals of the district.

$\begin{array}{cccccc}1 & 2 & 3 & 4 & 5 & 6 \\ \begin{array}{c}\text { STRONGLY } \\ \text { AGREE }\end{array} & \text { AGREE } & \begin{array}{c}\text { SLIGHTLY } \\ \text { AGREE }\end{array} & \begin{array}{l}\text { SLIGHTLY } \\ \text { DISAGREE }\end{array} & \text { DISAGREE } & \begin{array}{c}\text { DISAGREE } \\ \text { STRONGLY }\end{array}\end{array}$

8) Visibility and portability of the computers.

$\begin{array}{cccccc}1 & 2 & 3 & 4 & 5 & 6 \\ \begin{array}{c}\text { STRONGLY } \\ \text { AGREE }\end{array} & \text { AGREE } & \begin{array}{c}\text { SLIGHTLY } \\ \text { AGREE }\end{array} & \begin{array}{l}\text { SLIGHTLY } \\ \text { DISAGREE }\end{array} & \text { DISAGREE } & \begin{array}{c}\text { DISAGREE } \\ \text { STRONGLY }\end{array}\end{array}$

9) Interactive nature of the computers.

$\begin{array}{cccccc}1 & 2 & 3 & 4 & 5 & 6 \\ \begin{array}{c}\text { STRONGLY } \\ \text { AGREE }\end{array} & \text { AGREE } & \begin{array}{c}\text { SLIGHTLY } \\ \text { AGREE }\end{array} & \begin{array}{l}\text { SLIGHTLY } \\ \text { DISAGREE }\end{array} & \text { DISAGREE } & \begin{array}{c}\text { DISAGREE } \\ \text { STRONGLY }\end{array}\end{array}$

10) Decentralized decision-making regarding actual use of the innovation.

$\begin{array}{cccccc}1 & 2 & 3 & 4 & 5 & 6 \\ \begin{array}{c}\text { STRONGLY } \\ \text { AGREE }\end{array} & \text { AGREE } & \begin{array}{c}\text { SLIGHTLY } \\ \text { AGREE }\end{array} & \begin{array}{l}\text { SLIGHTLY } \\ \text { DISAGREE }\end{array} & \text { DISAGREE } & \begin{array}{c}\text { DISAGREE } \\ \text { STRONGLY }\end{array}\end{array}$

11) Support of the principals in each school.

$\begin{array}{cccccc}1 & 2 & 3 & 4 & 5 & 6 \\ \begin{array}{c}\text { STRONGLY } \\ \text { AGREE }\end{array} & \text { AGREE } & \begin{array}{c}\text { SLIGHTLY } \\ \text { AGREE }\end{array} & \begin{array}{l}\text { SLIGHTLY } \\ \text { DISAGREE }\end{array} & \text { DISAGREE } & \text { DISAGREE } \\ \text { STRONGLY }\end{array}$

12) Provision for adequate teacher training and incentives to innovate.

$\begin{array}{cccccc}1 & 2 & 3 & 4 & 5 & 6 \\ \begin{array}{c}\text { STRONGLY } \\ \text { AGREE }\end{array} & \text { AGREE } & \begin{array}{c}\text { SLIGHTLY } \\ \text { AGREE }\end{array} & \begin{array}{l}\text { SLIGHTLY } \\ \text { DISAGREE }\end{array} & \text { DISAGREE } & \begin{array}{c}\text { DISAGREE } \\ \text { STRONGLY }\end{array}\end{array}$




\section{Integrating Computers into the Classroom}

\section{ENHANCERS}

CODE

13) High level of participation of teachers in the development of materials and curriculum.

$\begin{array}{cccccc}1 & 2 & 3 & 4 & 5 & 6 \\ \begin{array}{c}\text { STRONGLY } \\ \text { AGREE }\end{array} & \text { AGREE } & \begin{array}{c}\text { SLIGHTLY } \\ \text { AGREE }\end{array} & \begin{array}{l}\text { SLIGHTLY } \\ \text { DISAGREE }\end{array} & \text { DISAGREE } & \begin{array}{c}\text { DISAGREE } \\ \text { STRONGLY }\end{array}\end{array}$

14) Enthusiasm of students for computers.

$\begin{array}{cccccc}1 & 2 & 3 & 4 & 5 & 6 \\ \begin{array}{c}\text { STRONGLY } \\ \text { AGREE }\end{array} & \text { AGREE } & \begin{array}{c}\text { SLIGHTLY } \\ \text { AGREE }\end{array} & \begin{array}{l}\text { SLIGHTLY } \\ \text { DISAGREE }\end{array} & \text { DISAGREE } & \text { DISAGREE } \\ & & & & & \text { STRONGLY }\end{array}$

15) Collegiality among all users.

$\begin{array}{cccccc}1 & 2 & 3 & 4 & 5 & 6 \\ \begin{array}{c}\text { STRONGLY } \\ \text { AGREE }\end{array} & \text { AGREE } & \begin{array}{c}\text { SLIGHTLY } \\ \text { AGREE }\end{array} & \begin{array}{l}\text { SLIGHTLY } \\ \text { DISAGREE }\end{array} & \text { DISAGREE } & \begin{array}{c}\text { DISAGREE } \\ \text { STRONGLY }\end{array}\end{array}$

16) School support for using computers for consequential activities.

17) Small class size.

$\begin{array}{cccccc}1 & 2 & 3 & 4 & 5 & 6 \\ \begin{array}{c}\text { STRONGLY } \\ \text { AGREE }\end{array} & \text { AGREE } & \begin{array}{c}\text { SLIGHTLY } \\ \text { AGREE }\end{array} & \begin{array}{l}\text { SLIGHTLY } \\ \text { DISAGREE }\end{array} & \text { DISAGREE } & \text { DISAGREE } \\ \text { STRONGLY }\end{array}$

$\begin{array}{cccccc}1 & 2 & 3 & 4 & 5 & 6 \\ \begin{array}{c}\text { STRONGLY } \\ \text { AGREE }\end{array} & \text { AGREE } & \begin{array}{c}\text { SLIGHTLY } \\ \text { AGREE }\end{array} & \begin{array}{l}\text { SLIGHTLY } \\ \text { DISAGREE }\end{array} & \text { DISAGREE } & \begin{array}{c}\text { DISAGREE } \\ \text { STRONGLY }\end{array}\end{array}$

18) Innovativeness or willing to change.

$\begin{array}{cccccc}1 & 2 & 3 & 4 & 5 & 6 \\ \begin{array}{c}\text { STRONGLY } \\ \text { AGREE }\end{array} & \text { AGREE } & \begin{array}{c}\text { SLIGHTLY } \\ \text { AGREE }\end{array} & \begin{array}{l}\text { SLIGHTLY } \\ \text { DISAGREE }\end{array} & \text { DISAGREE } & \begin{array}{c}\text { DISAGREE } \\ \text { STRONGLY }\end{array}\end{array}$

19) Assisting teachers and students in feeling competent.

\begin{tabular}{|c|c|c|c|c|c|}
\hline 1 & 3 & 4 & 5 & & \\
\hline $\begin{array}{l}\text { STRONGLY } \\
\text { AGREE }\end{array}$ & AGREE & $\begin{array}{l}\text { SLIGHTLY } \\
\text { AGREE }\end{array}$ & $\begin{array}{l}\text { SLIGHTLY } \\
\text { DISAGREE }\end{array}$ & DISAGREE & $\begin{array}{l}\text { DISAGREE } \\
\text { STRONGLY }\end{array}$ \\
\hline
\end{tabular}




\section{APPENDIX B}

\section{Integrating Computers into the Classroom}

\section{INHIBITORS CODE}

Below are listed twenty-one (21) inhibitors to the integration of computers into the

classroom. (Please circle the trait that best indicates the degree of importance you perceive each of the Inhibitors.)

1) Lack of strong leadership.

$\begin{array}{cccccc}1 & 2 & 3 & 4 & 5 & 6 \\ \begin{array}{c}\text { STRONGLY } \\ \text { AGREE }\end{array} & \text { AGREE } & \begin{array}{c}\text { SLIGHTLY } \\ \text { AGREE }\end{array} & \begin{array}{l}\text { SLIGHTLY } \\ \text { DISAGREE }\end{array} & \text { DISAGREE } & \text { DISAGREE } \\ \text { STRONGLY }\end{array}$

2) Lack of appropriate training for teachers, administrators, and students.

$\begin{array}{lccccc}1 & 2 & 3 & 4 & 5 & 6 \\ \text { STRONGLY } & \text { AGREE } & \text { SLIGHTLY } & \text { SLIGHTLY } & \text { DISAGREE } & \text { DISAGREE } \\ \text { AGREE } & & \text { AGREE } & \text { DISAGREE } & & \end{array}$

STRONGLY

3) Inadequate financial planning.

$\begin{array}{crrccc}1 & 2 & 3 & 4 & 5 & 6 \\ \begin{array}{c}\text { STRONGLY } \\ \text { AGREE }\end{array} & \text { AGREE } & \begin{array}{c}\text { SLIGHTLY } \\ \text { AGREE }\end{array} & \begin{array}{c}\text { SLIGHTLY } \\ \text { DISAGREE }\end{array} & \text { DISAGREE } & \begin{array}{c}\text { DISAGREE } \\ \text { STRONGLY }\end{array}\end{array}$

4) Teacher attitude.

$\begin{array}{cccccc}1 & 2 & 3 & 4 & 5 & 6 \\ \begin{array}{c}\text { STRONGLY } \\ \text { AGREE }\end{array} & \text { AGREE } & \begin{array}{c}\text { SLIGHTLY } \\ \text { AGREE }\end{array} & \begin{array}{c}\text { SLIGHTLY } \\ \text { DISAGREE }\end{array} & \text { DISAGREE } & \begin{array}{c}\text { DISAGREE } \\ \text { STRONGLY }\end{array}\end{array}$

5) Lack of school day time for learning and using technology.

$\begin{array}{cccccc}1 & 2 & 3 & 4 & 5 & 6 \\ \begin{array}{c}\text { STRONGLY } \\ \text { AGREE }\end{array} & \text { AGREE } & \begin{array}{c}\text { SLIGHTLY } \\ \text { AGREE }\end{array} & \begin{array}{c}\text { SLIGHTLY } \\ \text { DISAGREE }\end{array} & \text { DISAGREE } & \text { DISAGREE } \\ \text { STRONGLY }\end{array}$

6) Lack of teachers' ability to design meaningful educational activities.

$\begin{array}{cccccc}1 & 2 & 3 & 4 & 5 & 6 \\ \begin{array}{c}\text { STRONGLY } \\ \text { AGREE }\end{array} & \text { AGREE } & \begin{array}{c}\text { SLIGHTLY } \\ \text { AGREE }\end{array} & \begin{array}{c}\text { SLIGHTLY } \\ \text { DISAGREE }\end{array} & \text { DISAGREE } & \begin{array}{c}\text { DISAGREE } \\ \text { STRONGLY }\end{array}\end{array}$




\section{Integrating Computers into the Classroom}

\section{INHIBITORS}

7) Inadequate computer skills.

$\begin{array}{cccc}1 & 2 & 3 & 4 \\ \begin{array}{c}\text { STRONGLY } \\ \text { AGREE }\end{array} & \text { AGREE } & \begin{array}{c}\text { SLIGHTLY } \\ \text { AGREE }\end{array} & \begin{array}{c}\text { SLIGHTLY } \\ \text { DISAGREE }\end{array}\end{array}$

8) Lack of skill on how to incorporate technology into the classroom curriculum.

$\begin{array}{cccc}1 & 2 & 3 & 4 \\ \text { STRONGLY } & \text { AGREE } & \text { SLIGHTLY } & \text { SLIGHTLY } \\ \text { AGREE } & & \text { AGREE } & \text { DISAGREE }\end{array}$

9) Failure to develop a long term plan.

$\begin{array}{cccccc}1 & 2 & 3 & 4 & 5 & 6 \\ \begin{array}{c}\text { STRONGLY } \\ \text { AGREE }\end{array} & \text { AGREE } & \begin{array}{c}\text { SLIGHTLY } \\ \text { AGREE }\end{array} & \begin{array}{c}\text { SLIGHTLY } \\ \text { DISAGREE }\end{array} & \text { DISAGREE } & \begin{array}{c}\text { DISAGREE } \\ \text { STRONGLY }\end{array}\end{array}$

10) Inadequate training of administrators, teachers, and students.

$\begin{array}{cccccc}1 & 2 & 3 & 4 & 5 & 6 \\ \begin{array}{c}\text { STRONGLY } \\ \text { AGREE }\end{array} & \text { AGREE } & \begin{array}{c}\text { SLIGHTLY } \\ \text { AGREE }\end{array} & \begin{array}{c}\text { SLIGHTLY } \\ \text { DISAGREE }\end{array} & \text { DISAGREE } & \text { DISAGREE } \\ & & \begin{array}{lll}\text { STRONGLY }\end{array}\end{array}$

11) Lack of a long term plan.

$\begin{array}{cccc}1 & 2 & 3 & 4 \\ \begin{array}{c}\text { STRONGLY } \\ \text { AGREE }\end{array} & \text { AGREE } & \begin{array}{c}\text { SLIGHTLY } \\ \text { AGREE }\end{array} & \begin{array}{c}\text { SLIGHTLY } \\ \text { DISAGREE }\end{array}\end{array}$

5

6

DISAGREE DISAGREE STRONGLY

12) Selection of appropriate hardware and software.

1

$3 \quad 4$

5

6
STRONGLY AGREE AGREE
SLIGHTLY SLIGHTLY AGREE DISAGREE

DISAGREE

DISAGREE STRONGLY

13) Lack of considering human resistance to change.

$\begin{array}{cccc}1 & 2 & 3 & 4 \\ \begin{array}{c}\text { STRONGLY } \\ \text { AGREE }\end{array} & \text { AGREE } & \begin{array}{c}\text { SLIGHTLY } \\ \text { AGREE }\end{array} & \begin{array}{c}\text { SLIGHTLY } \\ \text { DISAGREE }\end{array}\end{array}$

14) Lack of access to computers for use in the classroom.

$\begin{array}{cccccc}1 & 2 & 3 & 4 & 5 & 6 \\ \begin{array}{c}\text { STRONGLY } \\ \text { AGREE }\end{array} & \text { AGREE } & \begin{array}{c}\text { SLIGHTLY } \\ \text { AGREE }\end{array} & \begin{array}{c}\text { SLIGHTLY } \\ \text { DISAGREE }\end{array} & \text { DISAGREE } & \begin{array}{c}\text { DISAGREE } \\ \text { STRONGLY }\end{array}\end{array}$




\section{Integrating Computers into the Classroom}

\section{INHIBITORS}

15) Lack of teacher involvement in the construction of the plan.

\begin{tabular}{|c|c|c|c|}
\hline 1 & 2 & 3 & 4 \\
\hline STRONGLY & AGREE & SLIGHTLY & SLIGHTLY \\
\hline AGREE & & AGREE & DISAGREE \\
\hline
\end{tabular}

16) Lack of a financial plan.

$\begin{array}{cccc}1 & 2 & 3 & 4 \\ \begin{array}{c}\text { STRONGLY } \\ \text { AGREE }\end{array} & \text { AGREE } & \begin{array}{c}\text { SLIGHTLY } \\ \text { AGREE }\end{array} & \begin{array}{c}\text { SLIGHTLY } \\ \text { DISAGREE }\end{array}\end{array}$

17) Lack of time for teachers to learn how to use computer technology.

$\begin{array}{cccccc}1 & 2 & 3 & 4 & 5 & 6 \\ \begin{array}{c}\text { STRONGLY } \\ \text { AGREE }\end{array} & \text { AGREE } & \begin{array}{c}\text { SLIGHTLY } \\ \text { AGREE }\end{array} & \begin{array}{c}\text { SLIGHTLY } \\ \text { DISAGREE }\end{array} & \text { DISAGREE } & \begin{array}{c}\text { DISAGREE } \\ \text { STRONGLY }\end{array}\end{array}$

18) Lack of motivation for teachers.

$\begin{array}{cccc}1 & 2 & 3 & 4 \\ \begin{array}{c}\text { STRONGLY } \\ \text { AGREE }\end{array} & \text { AGREE } & \begin{array}{c}\text { SLIGHTLY } \\ \text { AGREE }\end{array} & \begin{array}{c}\text { SLIGHTLY } \\ \text { DISAGREE }\end{array}\end{array}$

19) Lack of teacher involvement in selecting appropriate hardware and software.

$\begin{array}{cccc}1 & 2 & 3 & 4 \\ \text { STRONGLY } & \text { AGREE } & \text { SLIGHTLY } & \text { SLIGHTLY } \\ \text { AGREE } & & \text { AGREE } & \text { DISAGREE }\end{array}$

20) Lack of an instructional model for teachers to maximize the use of computers.

$\begin{array}{cccc}1 & 2 & 3 & 4 \\ \text { STRONGLY } & \text { AGREE } & \begin{array}{c}\text { SLIGHTLY } \\ \text { AGREE }\end{array} & \text { SLIGHTLY } \\ \text { AGISAGREE }\end{array}$

5

DISAGREE DISAGREE

21) Lack of skills in the use of computers.

$\begin{array}{cccccc}1 & 2 & 3 & 4 & 5 & 6 \\ \begin{array}{c}\text { STRONGLY } \\ \text { AGREE }\end{array} & \text { AGREE } & \begin{array}{c}\text { SLIGHTLY } \\ \text { AGREE }\end{array} & \begin{array}{c}\text { SLIGHTLY } \\ \text { DISAGREE }\end{array} & \text { DISAGREE } & \begin{array}{c}\text { DISAGREE } \\ \text { STRONGLY }\end{array}\end{array}$


May 10,1999

\section{Dear Participant,}

I am a doctoral student in the Technology Education Program, College of Human and Education, at West Virginia University, and I am asking you to participate in this study for my dissertation. Your responses will remain anonymous. You do not have to respond to every item. However, this study will be stronger if you choose to do so. Your participation is voluntary and if you do participate your name and your districts name will be held in strict confidence.

The purpose of this research is to determine what educators believe to be the primary Inhibitors and Enhancers to integrating computers into the classroom curriculum. The two Likert scales used in this research are of the same in design. Likert scale (1) is a six-point scale and is focused on nineteen statements Enhancers to the integration of computers into the classroom. Likert scale (2) is a six-point scale and is focused on twenty-one statements Inhibitors to the integration of computers into the classroom curriculum.

The amount of time required to complete Inhibitor questionnaire (1), and the Enhancer questionnaire (2) will vary between fifteen and twenty minutes for both. When you have completed both questionnaires and the demographic page please return the survey to the administrative secretary.

From those who return completed questionnaires two participants will be randomly selected and each will receive a Fifty-dollar gift certificate to the Somerset Mall. Please return your completed questionnaires by May 28, 1999. If you have any questions please contact me at 814-395-3622 or you may contact my advisor Dr. George Maughan at 304-293-3803 ext 1702.

Sincerely,

Edward D Jeffreys

Doctoral Candidate

West Virginia University 